\title{
Translational Insights into Extremely Low Frequency Pulsed Electromagnetic Fields (ELF-PEMFs) for Bone Regeneration after Trauma and Orthopedic Surgery
}

\author{
Sabrina Ehnert ${ }^{1, *(1)}$, Steffen Schröter ${ }^{1}$, Romina H. Aspera-Werz ${ }^{1}$, Wiebke Eisler ${ }^{1}$, \\ Karsten Falldorf ${ }^{2}$, Michael Ronniger ${ }^{2}$ and Andreas K. Nussler ${ }^{1}$ (D) \\ 1 Siegfried Weller Institute for Trauma Research, Depterment of Trauma and Reconstructive Surgery, \\ BG Unfallklinik Tübingen, Eberhard Karls Universität Tübingen, D-72076 Tübingen, Germany; \\ sschroeter@bgu-tuebingen.de (S.S.); rominaaspera@hotmail.com (R.H.A.-W.); \\ weisler@bgu-tuebingen.de (W.E.); andreas.nuessler@gmail.com (A.K.N.) \\ 2 Sachtleben GmbH, Hamburg, Haus Spectrum am UKE, Martinistraße 64, D-20251 Hamburg, Germany; \\ falldorf@citresearch.de (K.F.); ronniger@citresearch.de (M.R.) \\ * Correspondence: sabrina.ehnert@med.uni-tuebingen.de or sabrina.ehnert@gmail.com; \\ Tel.: +49-7071-606-1067
}

Received: 30 September 2019; Accepted: 18 November 2019; Published: 20 November 2019

\begin{abstract}
The finding that alterations in electrical potential play an important role in the mechanical stimulation of the bone provoked hype that noninvasive extremely low frequency pulsed electromagnetic fields (ELF-PEMF) can be used to support healing of bone and osteochondral defects. This resulted in the development of many ELF-PEMF devices for clinical use. Due to the resulting diversity of the ELF-PEMF characteristics regarding treatment regimen, and reported results, exposure to ELF-PEMFs is generally not among the guidelines to treat bone and osteochondral defects. Notwithstanding, here we show that there is strong evidence for ELF-PEMF treatment. We give a short, confined overview of in vitro studies investigating effects of ELF-PEMF treatment on bone cells, highlighting likely mechanisms. Subsequently, we summarize prospective and blinded studies, investigating the effect of ELF-PEMF treatment on acute bone fractures and bone fracture non-unions, osteotomies, spinal fusion, osteoporosis, and osteoarthritis. Although these studies favor the use of ELF-PEMF treatment, they likewise demonstrate the need for more defined and better controlled/monitored treatment modalities. However, to establish indication-oriented treatment regimen, profound knowledge of the underlying mechanisms in the sense of cellular pathways/events triggered is required, highlighting the need for more systematic studies to unravel optimal treatment conditions.
\end{abstract}

Keywords: extremely low frequency pulsed electromagnetic fields (ELF-PEMF); bone regeneration; fracture healing; spinal fusion; osteoporosis; bone mineral density; osteoarthritis; pain; bone cells

\section{Background}

It is well accepted that bone is a mechanosensory organ, which requires continuous strain to preserve its functional structure and prevent disuse bone loss (osteopenia or osteoporosis). The resulting premise that bones constantly adapt to meet their mechanical demands is referred to as Wolff's law [1]. In the 1960s, it was first reported that mechanical strain alters the electrical potential along the lateral and longitudinal axes of compact bone, providing local stimuli for bone-forming cells [2]. Bassett 
and colleagues suggest collagen piezoelectricity as a potential underlying mechanism. According to their theory, applied stress generates local potential gradients along the collagen fibers $[3,4]$. This mechanism, ascribed to the non-centrosymmetric nature of collagen, is well accepted for dry bone tissue [5]. However, for wet bone tissue, there was more and more experimental evidence that fluid-induced shear stress and associated streaming potentials cause the strain-generated potentials [6]. Offering a possible explanation of how bone is selectively deposited at mechanically challenged areas, these described phenomena raised hope in the scientific community that these mechanisms can be utilized to support bone function and fracture healing. Anecdotal reports that electromagnetic fields fostered healing of persistent non-union fractures further fueled the interest in this area [7-10]. In these studies, mainly extremely low frequency pulsed electromagnetic fields (ELF-PEMFs) have been applied.

ELF-PEMFs represent a subclass of electromagnetic fields. With frequencies or repetition rates (often used synonymously when describing PEMFs) up to a few hundred Hz, ELF-PEMFs are situated at the lower end of the electromagnetic spectrum (Figure 1).

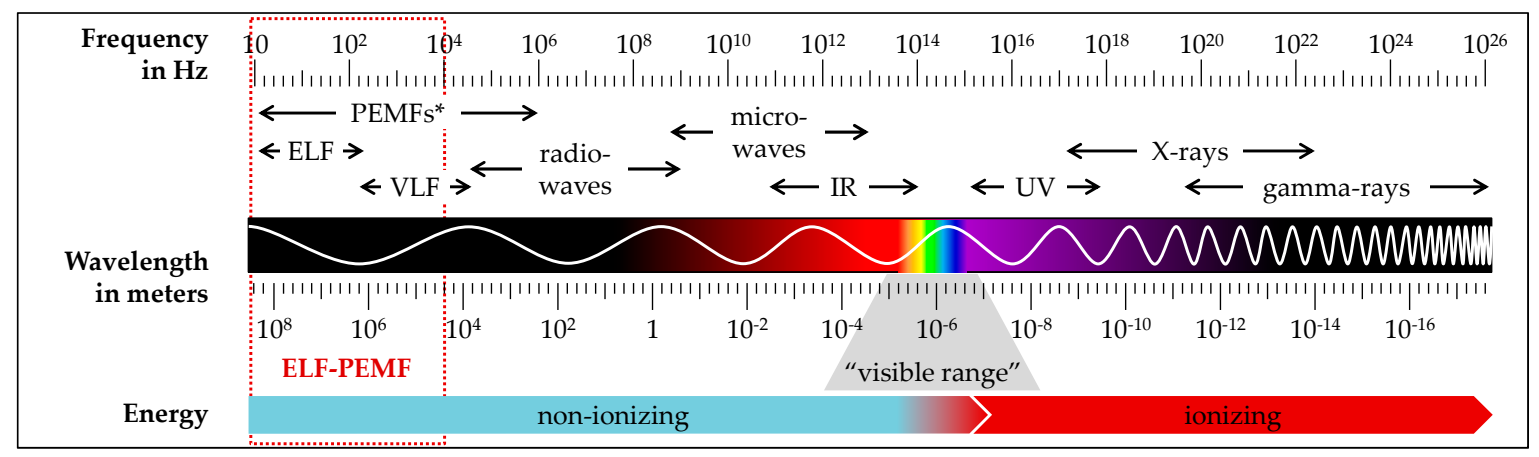

Figure 1. The electromagnetic spectrum with its characteristic frequencies, wavelengths, and electromagnetic energy. The electromagnetic spectrum ranges from extremely long wavelengths with small frequencies (e.g., ELFs (extremely low frequency) and VLFs (very low frequency)) to extremely short wavelengths with high frequencies (e.g., UV (ultraviolet), x-rays or gamma-rays). Depending on the wavelength and frequency, it comprises both nonionizing and ionizing radiation. * In case for pulsed electromagnetic fields (PEMFs), "frequency" and "repetition rate" are often used synonymously, knowing that lower-frequency electromagnetic pulses are super-positioned by higher frequencies, yielding a wider frequency spectrum. The range of extremely low frequency pulsed electromagnetic fields (ELF-PEMFs) considered in this review is marked in red.

However, the Fourier-frequency spectrum of a signal can range from extremely low $(\leq 300 \mathrm{~Hz})$ to high frequencies $(1 \mathrm{kHz}$ to $\leq 1 \mathrm{MHz})$, whereas the latter reflects the higher frequency pulse repetition rate $f$ (for definition, see Figure 2). In pulsed EMF (PEMF), bursts of pulses are sent in on-off periods. The extremely low frequency (ELF) notation can reflect the burst or the pulse repetition rate. ELF-PEMF radiation is nonionizing and uses electrical energy to direct a series of magnetic pulses through biological tissue. Each of the magnetic pulses induces a tiny electrical signal in the exposed tissue that is thought to stimulate tissue repair without inducing significant thermal effects [11]. 


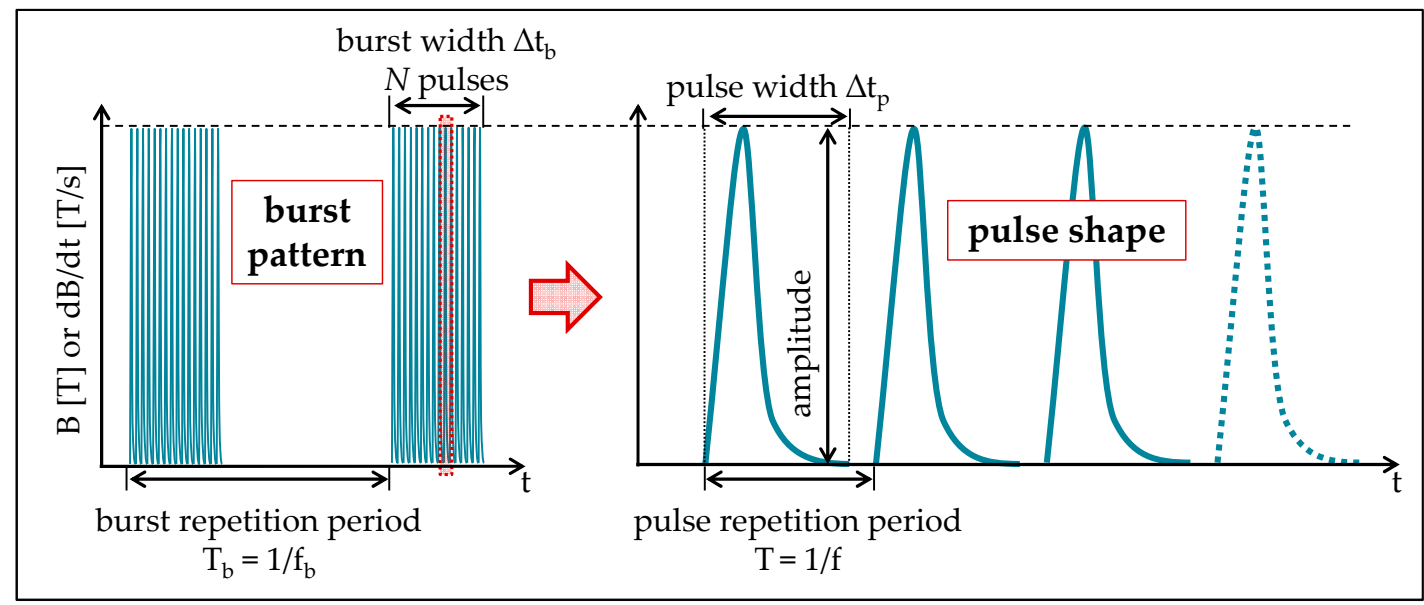

Figure 2. Schematic overview of the terms used for characterizing bursts and pulses of ELF-PEMF. PEMF-signals use periodically repeated bursts consisting of a certain number of pulses, $N$, at a certain frequency, $f$. The pulses can be described by their shape, amplitude, and pulse width, $\Delta t_{p}$. Here, bursts are repeated at the burst-frequency $\mathrm{f}_{\mathrm{b}} \ll \mathrm{f}$. Some publications refer to the magnetic flux density, $\mathrm{B}$, or the time-derivative of the magnetic field, $\mathrm{dB} / \mathrm{dt}$, others only state the search coil induction voltage. However, without knowing the exact search coil dimensions, the magnetic field amplitude cannot be derived from this value.

\section{In Vitro Evidence for ELF-PEMF Effects on Bone Cells}

Within the bioelectromagnetic science society, certain theories on how natural and artificial ELF-PEMF may induce cellular effects on the molecular level are discussed, for example, the molecular gyroscope model [12], Lorentz models [13,14], DNA antenna model [15], radical pair model [16], and ion cyclotron resonance [17]. Cells in the human body are continuously exposed to electrical charges (e.g., $\mathrm{Na}^{2+}, \mathrm{K}^{+}$, or $\mathrm{Cl}^{-}$ion gradients, which regulate cellular membrane potentials) involved in a manifold of cellular processes [18]. Therefore, it is also feasible that ELF-PEMFs influence cellular responses by influencing these natural ion gradients, either passively by ionic forces or actively by regulating so-called voltage-gated ion channels [19-21]. However, it might well be that the effects triggered by ELF-PEMFs can be only explained by a combination of these theories. Focusing on the bone, studies have demonstrated that ELF-PEMF treatment is reported to cause calcium flux, induce RNA expression, stimulate synthesis of extracellular matrix proteins and growth factors, and initiate signaling cascades involved in viability, proliferation, and differentiation. Some of these ELF-PEMF effects on viability, growth, and function of bone cells will be described in more detail in the following paragraphs.

\subsection{ELF-PEMF Effects on Viability of Bone Cells}

Since 50 years ago the first suspicion arose that electromagnetic fields, especially those created by $50 / 60 \mathrm{~Hz}$ power lines, may cause possible health risks [22], many in vitro experiments frequently addressed the question, whether ELF-PEMFs affect cell viability. Considering that ELF-PEMFs are located at the lower, nonionizing, and nonthermal range of the electromagnetic spectrum, a direct temperature-associated damage of DNA or proteins may be excluded. Several studies have shown that ELF-PEMF treatment may induce formation of reactive oxygen species (ROS) $[23,24]$, which may affect cell viability. Accumulation of ROS or oxidative stress, causing upregulation of heat shock proteins and direct damage of the DNA, was mainly observed when cells are exposed to EMFs in the micro- and radio-frequency range [25]. However, Chang et al. showed ROS induction in osteoclasts exposed to ELF-PEMF, which significantly enhanced apoptosis in these cells, especially with prolonged treatment durations [26]. Contrarily, Tang and Zhao showed reduced apoptosis rates in primary mouse osteoblasts and ROS cells exposed to ELF-PEMF $(f=50 \mathrm{~Hz})$ [27]. This might be 
partly explained by our own study, which showed ROS (mainly $\bullet \mathrm{O}_{2}{ }^{-}$and $\mathrm{H}_{2} \mathrm{O}_{2}$ ) formation caused by repetitive ELF-PEMF exposure $(\mathrm{f}=16 \mathrm{~Hz})$ induced expression and activity of antioxidative enzymes, for example, superoxide dismutase (SOD), catalase (CAT), glutathione peroxidase (GPX), and glutathione-disulfide reductase (GSR). These enzymes, being involved in the mitochondrial degradation of ROS, are essential for the survival of organisms and their health [28]. In line with this, the work of Raggi et al. showed that repetitive exposure ( $27 \mathrm{~min}$ per day for 10 days) to ELF-PEMF reduced oxidative stress measures in blood of healthy volunteers for up to 1 month after the treatment [29]. Considering that ROS are generally produced as by-products of the mitochondrial respiratory chain, increased ROS levels after ELF-PEMF exposure might indicate towards increased proliferation or enhanced function in these cells.

\subsection{ELF-PEMF Effects on Bone Cell Growth}

Zhang et al. investigated the effect of $\mathrm{f}=15 \mathrm{~Hz}$ EMFs with different waveforms, namely rectangular (ELF-REMF), triangular (ELF-TEMF), sinusoidal (ELF-SEMF), and ELF-PEMF, on proliferation of primary rat calvaria cells. In their experiments, only ELF-PEMF and ELF-REMF induced proliferation. ELF-SEMF even harmed cell growth [30]. This is in line with the work of Zhou et al., who showed comparable effects in primary rat calvaria cells exposed to $\mathrm{f}=50 \mathrm{~Hz}$ ELF-SEMF, ELF-TEMF, and ELF-REMF [31]. This, in turn, suggests that altering the frequency ( $\mathrm{f}=15 \mathrm{vs}$. $50 \mathrm{~Hz}$ ) less strongly affects bone cell proliferation than altering the waveform. This assumption is supported by our work, where ELF-PEMFs with different frequencies in the range from $\mathrm{f}=10$ to $90.6 \mathrm{~Hz}$ all induced proliferation $(\sim 50 \%)$ of primary human osteoblasts in equal measures [32]. The work of Tang and Zhao showed an increase in $\mathrm{S}$ phase in primary mouse osteoblasts and ROS cells after exposure to $\mathrm{f}=50 \mathrm{~Hz}$ ELF-PEMF [27], indicating towards an increase in cell proliferation. In line with this, Wei et al. showed that exposure to $\mathrm{f}=48 \mathrm{~Hz}$ ELF-PEMF promoted proliferation (increased number of cells in $S$ and G(2)M phase) of primary rat calvaria cells but not of MC3T3-E1 cells [33], suggesting that the observed effect is strongly dependent on the differentiation status of the cells. Bique et al. observed similar effects in strongly differentiated SaOs-2 cells and less differentiated MC3T3-E1 cells exposed to $\mathrm{f}=50 \mathrm{~Hz}$ ELF-PEMF [34]. This finding is supported by the work of Kaivosoja et al., which showed stimulatory effects of $\mathrm{f}=15 \mathrm{~Hz}$ ELF-PEMF on proliferation being more pronounced in SaOs- 2 cells when compared with less differentiated mesenchymal stem cells [35]. Yamaguchi et al. proposed that ELF-PEMF-dependent alterations in intercellular gap junction communication might be responsible for this effect, as in their experiments, exposure to a $\mathrm{f}=120 \mathrm{~Hz}$ ELF-PEMF rapidly (within $1 \mathrm{~h}$ ) decreased intercellular gap junction communication only in immature MC3T3 cells, but not in more mature cell types. Interestingly, this phenomenon was not dependent on the applied frequencies $(f=30,60$, or $120 \mathrm{~Hz}$ ) but linearly correlated with the intensity of the fields [36]. This finding is supported by the work of Lohmann et al., which showed changes in Connexin 43 levels in ROS 17/2.8 and MLO-Y4 cells within 3 days following $\mathrm{f}=15 \mathrm{~Hz}$ ELF-PEMF exposure [37].

\subsection{ELF-PEMF Effects on Bone Cell Function}

Zhou et al. not only showed a waveform-dependent effect of ELF-PEMFs ( $f=50 \mathrm{~Hz}$ ) on proliferation, but also on osteogenic differentiation of primary rat calvaria cells. In their experiments, osteoblastic markers, e.g., alkaline phosphatase (ALP) and mineralized matrix, were induced only by ELF-TEMF and to a lesser extent by ELF-SEMF [31]. Comparable results were observed by Zhang et al., who showed enhanced matrix mineralization only in primary rat calvaria cells exposed to $\mathrm{f}=15 \mathrm{~Hz}$ ELF-TEMF and ELF-PEMF, but not to ELF-SEMF [30]. The authors suggest extracellular calcium, $\mathrm{P} 2$ receptor on the membrane, and phospholipase $\mathrm{C}$ pathway being involved in the observed effects of the ELF-PEMF treatment [30]. ELF-PEMF modulation of calcium influx is reported by several studies, proposedly via voltage-gated calcium channels [38-42]. Increased calcium influx, in turn, may activate specific potassium channels [19]. Comparable ELF-PEMF effects have been reported for a large variety of ion channels and membrane receptors involved in membrane trafficking 
(for overview, see [43]). Resulting alterations in ion gradients affect several intracellular phenomena, for example, cell volume or signal transduction [19]. For example, Sollazzo et al. showed activation of protein kinase B and signal transducer and activator of transcription (STAT) 3 (both known to regulate bone metabolism [44-46]) signaling in MG-63 cells exposed to $\mathrm{f}=75 \mathrm{~Hz}$ ELF-PEMF [47]. Furthermore, ELF-PEMF exposure not only induced expression of transforming growth factor beta (TGF- $\beta$ ) and bone morphogenetic proteins (BMPs), but also enhanced their signaling [48-53]. Similar was observed for the Wnt/ $\beta$-catenin signaling pathway [40,54-58], known to be strongly activated by calcium influx. However, Wnt, TGF- $\beta$, and BMP signaling may also be regulated by the cells' primary cilia $[59,60]$, which are cellular structures reported to be affected by ELF-PEMF $[43,48,61,62]$. Therefore, it is feasible that ELF-PEMF affect primary cilia structure and function.

In our study, increased osteogenic function (ALP activity and matrix mineralization) was associated with an activation of extracellular signal-regulated kinase (ERK) 1/2 signaling [32], proposedly induced by ROS [24]. In certain bone modeling phases, ROS may activate osteoclasts while inhibiting osteoblasts [63]. By inducing ROS, ELF-PEMF thus may favor osteoclastogenesis, an assumption supported by the studies of $\mathrm{Pi}$ and Zhang $[64,65]$. However, there are also several other reports showing ELF-PEMF inhibitory effects on osteoclastogenesis [66-68]. He et al. suggest that ELF-PEMF suppressive effects are mediated by endocrine effects of osteoblasts [67], a hypothesis supported by several other studies [61,69-72]. While Wang et al. proposed that regulation of osteoclastogenesis is strongly dependent on the intensity of the applied ELF-PEMF [73], Lei et al. showed bone metabolic ELF-PEMF effects in osteoporotic (ovariectomized) mice which strongly depended on the frequency range applied [74]. While lower frequencies induced osteoblast function, higher frequencies inhibited osteoclast function [74]. This is in line with our previous work, showing that the ELF-PEMF with a frequency of $\mathrm{f}=16 \mathrm{~Hz}$, which most effectively induced osteoblast function, did not affect osteoclast function [32]. Applying the same ELF-PEMF with an only $10 \mathrm{~Hz}$ higher frequency, however, resulted in an increased osteoclast function [75].

Bagheri et al. showed that continuous exposure to $\mathrm{f}=75 \mathrm{~Hz}$ ELF-PEMF increased the expression of ALP, Runx2, and Osterix [76]. In line with this, Sollazzo et al. showed increased expression of fibronectin (FN), vinculin (VCL), collagen (COL1A2), osteonectin, and tissue inhibitor for matrix-metalloproteinase 1 (TIMP1) in MG-63 cells exposed to $\mathrm{f}=75 \mathrm{~Hz}$ ELF-PEMF [47]. At the same time, expression of proteins involved in extracellular matrix (ECM) degradation (e.g., matrix-metalloproteinase 11 (MMP11)) decreased in these cells [47]. These results might be partly explained by the work of Blank and Goodman, which identified specific EMF-responsive DNA sequences, so-called nCTCTn sequences, which are thought to regulate expression of genes (e.g., c-myc or hsp70) as an immediate and direct response to ELF-PEMF exposure [77,78].

Increased expression of osteogenic marker genes was accompanied with increased osteoblast function. The work of Lu et al. showed stimulatory effects of $f=20 \mathrm{~Hz}$ ELF-PEMF on ALP and Osteocalcin levels in rat-derived mesenchymal stem cells. In their experiments, ELF-PEMF exposure even suppressed adipogenic differentiation [79]. In line with this, both the study of Martino et al. [80] and the study of Hannay et al. [81] showed $\mathrm{f}=15 \mathrm{~Hz}$ ELF-PEMF stimulatory effects on ALP activity (within few hours) and matrix mineralization (within 2-4 days) of SaOs-2 cells. These results were comparable to our study, which showed a frequency-dependent increase in ALP activity and matrix mineralization in ELF-PEMF-exposed primary human osteoblasts [32].

Interestingly, in our study, the observed ELF-PEMF effect was most pronounced in cells with poor basal osteogenic function, suggesting that ELF-PEMF treatment might be most efficient in conditions where bone formation is somehow suppressed [32]. However, this assumption requires further investigation. Examples are the studies of Cai et al. [82], Li et al. [83], or Jing et al. [84], which investigated the effect of ELF-PEMF on architecture and mechanical properties of bone in diabetic animals, known to have skeletal deficiencies, or the studies of Lei et al. [74,85], Li et al. [86], Zhou et al. [87,88], or Androjna et al. [89], which investigated the effect of ELF-PEMF on bone quality in osteoporotic animals. 


\section{Clinical Studies on the Effect of ELF-PEMF Treatment on Bone}

In vitro studies and initial case reports hyped the use of ELF-PEMFs to support fracture healing and bone function starting in the 1970s, resulting in continuously increasing numbers of publications on the proposed subject (for overview, see search strategy at the end of the manuscript). However, a closer look on the studies available regarding ELF-PEMFs' bone effects quickly attenuates the hype. As claimed by existing systematic reviews and meta-analyses, many of these reports lack placebo controls [90-98]. Therefore, these studies can be counted as tolerance studies at best. However, a sizeable amount of prospective studies with adequate controls remains that can be used to judge possible effects of ELF-PEMFs on bone. These studies are summarized in the following paragraphs.

\subsection{ELF-PEMF Treatment for Pseudarthrosis and Non-Union Fractures}

There are only five studies on pseudarthrosis and fracture non-unions which compare ELF-PEMF treatment with placebo treatment in a prospective and blinded fashion (Figure 3). These studies use ELF-PEMFs with frequencies ranging from $15 \mathrm{~Hz}$ [99] to $200 \mathrm{kHz}$ [100]. Two studies used ELF-PEMF generators approved for medical use-BIOSTIM@(IGEA S.p.A., Carpi, Italy) [101] and Orthopulse®II (OSSATEC, Uden, The Netherlands) [100]. ELF-PEMF exposures were between 8 and $14 \mathrm{~h}$ per day for 3 to 12 months. Despite the different treatment conditions, ELF-PEMF treatment overall was able to induce healing of pseudarthrosis and non-union fractures (mean $\mathrm{OR}=3.70 \pm 1.02$ ). At first glance, it may seem that the higher frequencies applied were more effective than the lower frequencies applied. However, this cannot be generalized as ELF-PEMF parameters (e.g., field intensities) vary. Furthermore, other factors, for example, the patients' age or the persistence of the bone defect ( $\geq 1$ year vs. 4-6 months) have to be considered too. Overall, the most consistent results were obtained when ELF-PEMF treatment was started early during the development of a pseudarthrosis (delayed-union) [100]. The most pronounced effects, however, were observed when ELF-PEMF treatment was applied to patients with a pseudarthrosis persisting for $\geq 1$ year [102]. Although four of the studies were comparable for patients' age and follow-up time-points, the diversity in ELF-PEMF characteristics applied prevents reliable predictions on optimal treatment duration [99,100,102,103]. This is in contrast to the follow-up study, which summarized clinical outcomes of 1382 patients who received ELF-PEMF treatment $\left(\Delta \mathrm{t}_{\mathrm{b}}=4.5 \mathrm{~ms} ; \mathrm{f}_{\mathrm{b}}=15 \mathrm{~Hz}\right.$; peak amplitude intensity $=1.6 \mathrm{mT}$; $\Delta t_{p}=225 \mu \mathrm{s}$; generated with the EBI Bone Healing System; Zimmer Biomet, Warsaw, IN, USA) to support healing of acute, delayed, and non-union fractures. In this study, fracture healing was gradually accelerated with elongation of the daily exposure time, for example, fracture healing was significantly faster when the field was applied for $\geq 9 \mathrm{~h} / \mathrm{d}$ when compared with $<3 \mathrm{~h} / \mathrm{d}$ [104]. In contrast to the above-mentioned five prospective studies, this retrospective study refers to a larger study cohort. While the five prospective studies attempted to match the placebo-treated and the ELF-PEMF-treated patients regarding possible confounding factors, for example, age, nutritional status, alcohol or cigarette consumption, comorbidities (e.g., diabetes mellitus), or medication (e.g., corticosteroids or nonsteroidal anti-inflammatory drugs) $[105,106]$, this retrospective study lacks information on these patient characteristics, therefore, the conclusion that elongated ELF-PEMF exposure times are favorable for bone healing has to be handled with care. It might well be that therapy compliance decreased with an increasing number of confounding factors. et al. 


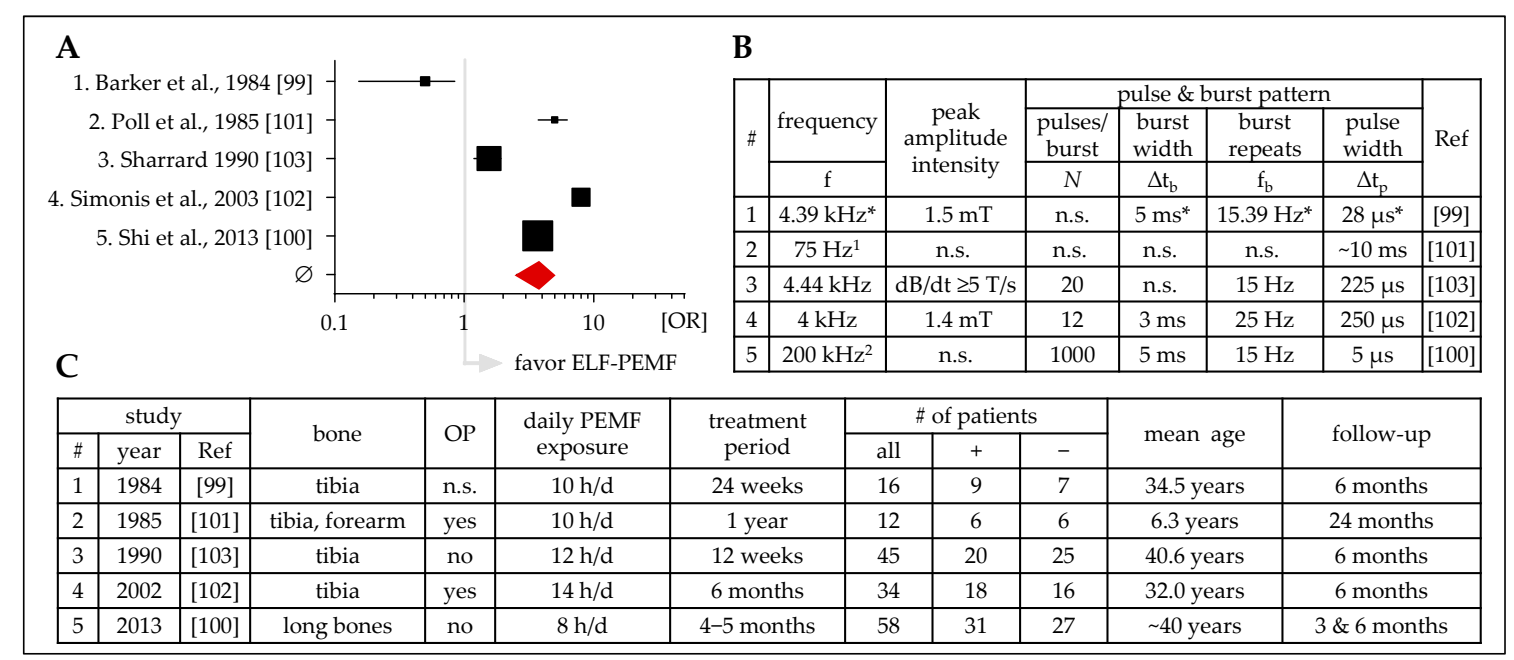

Figure 3. Overview on clinical studies (prospective, placebo-controlled, blinded) investigating the effects of ELF-PEMF treatment on healing of pseudarthrosis/non-union fractures. (A) Forest plot showing OR $\pm 95 \%$ C.I. - sum was calculated as described by Neyeloff et al. [107], with weighting based on sample size. (B) Tabular overview of the ELF-PEMF used in the presented studies. (C) Tabular overview of the presented studies including affected bones, number of patients, treatment, and follow up. ${ }^{1}$ BIOSTIM ${ }^{\circledR}$, IGEA S.p.A., Carpi, Italy; ${ }^{2}$ Orthopulse ${ }^{\circledR}$ II, OSSATEC, Uden, The Netherlands; $\mathrm{f}$ : frequency; $\Delta \mathrm{t}_{\mathrm{b}}$ : burst width; $\mathrm{f}_{\mathrm{b}}$ : burst repeats; $\Delta \mathrm{t}_{\mathrm{p}}$ : pulse width; OP: surgery; + ELF-PEMF treatment; - placebo treatment; n.s.: not specified; ${ }^{*}$ obtained from secondary source.

\subsection{ELF-PEMF Treatment to Support Acute Fracture Healing}

Similarly, there are five prospective and blinded studies investigating the effect of ELF-PEMF treatment on acute fracture healing for the femur [108,109], tibia [110], or scaphoid [111,112] (Figure 4). These studies use ELF-PEMFs with fixed frequencies [108,110-112] or a frequency range (5-105 Hz [109]). Three studies used ELF-PEMF generators approved for medical use-EBI Bone Healing System (Zimmer Biomet, Warsaw, IN, USA) [110] and Bone Growth Stimulator (OSSATEC, Uden, The Netherlands) [111,112]. Daily ELF-PEMF exposures were even more diverse than in the studies before and ranged from 1 to $24 \mathrm{~h}$ per day for periods of 42 to 90 days. Four studies were comparable regarding the patients' mean age (30 to 41 years vs. 69 years). Three studies considered earlier follow-up time-points ( 3 to 12 months). The other two studies considered later follow-up time-points (6 to 18 months and 12 to 24 months). Summarizing the five studies at the common 12 month follow-up time-point, ELF-PEMF treatment was able to support fracture healing (mean $\mathrm{OR}=2.86 \pm 0.59$ ). At the later time-points, the studies that applied higher-frequency ELF-PEMFs seemed to be more effective, while at the earlier follow-up time-points, the studies that applied lower-frequency ELF-PEMFs were able to further accelerate fracture healing [110-112]. Strongest effects were observed with an ELF-PEMF treatment of $75 \mathrm{~Hz}$ applied for $\geq 8 \mathrm{~h}$ per day for 90 days [108], however, it is not clear whether this effect is attributed to the higher frequency, other specific ELF-PEMF characteristics, and/or the higher age. Interestingly, solid results were observed when applying the ELF-PEMF with a range of frequencies-with this ELF-PEMF, a daily exposure of $1 \mathrm{~h}$ was sufficient to induce fracture healing [109]. In line with this, the study of Cheing et al. showed that $30 \mathrm{~min}$ ELF-PEMF $\left(\Delta \mathrm{t}_{\mathrm{b}}=\right.$ n.s.; $\mathrm{f}_{\mathrm{b}}=50 \mathrm{~Hz}$; peak amplitude intensity $=9.9 \mathrm{mT} ; \Delta \mathrm{t}_{\mathrm{p}}=\mathrm{n}$.s.; generated with the Pulsed Magnetic Field Therapy System-model XKC-660W; Magnetopulse International, Griffin, Australia) exposure daily for 5 days enhanced the effect of cooling-effectively reducing swelling and pain, this early (even before surgery) ELF-PEMF treatment significantly accelerated healing of radius fractures [113]. Similarly, Lazovic et al. were able to improve functional outcome after radius fracture with only $30 \mathrm{~min}$ ELF-PEMF $\left(\Delta \mathrm{t}_{\mathrm{b}}=\right.$ n.s.; $\mathrm{f}_{\mathrm{b}}=25 \mathrm{~Hz}$; peak amplitude intensity $=6 \mathrm{mT} ; \Delta t_{p}=$ n.s.; generated with the Elec System, Elbtal, Germany) exposure daily for 
10 days [114]. Knowing that very long and complicated treatment procedures reduce the patients' compliance [115], this study challenges the long daily exposure times and treatment duration used with the other studies.

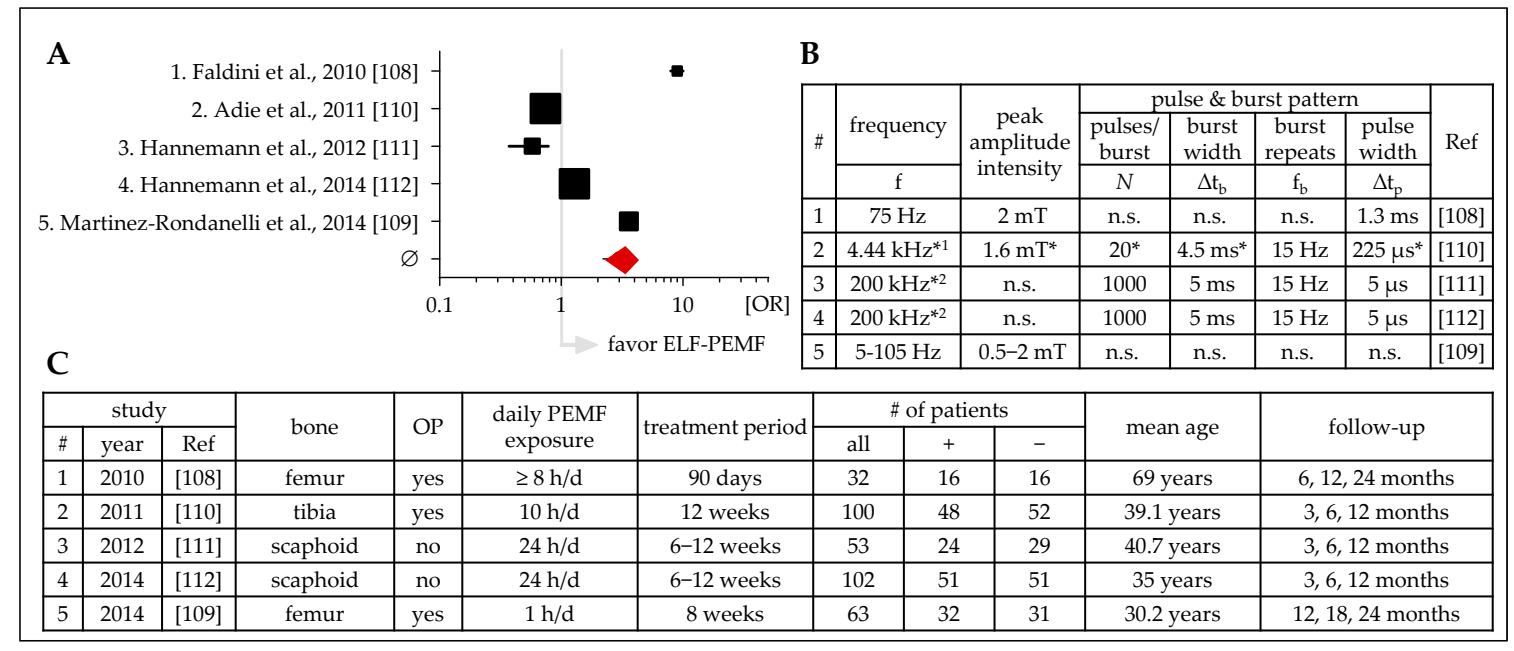

Figure 4. Clinical studies (prospective, placebo-controlled, blinded) investigating the effects of ELF-PEMF treatment on healing of acute fractures. (A) Forest plot showing OR $\pm 95 \%$ C.I.-sum was calculated as described by Neyeloff et al. [107], with weighting based on sample size. (B) Overview on the ELF-PEMF used in the presented studies. (C) Overview on the presented studies including affected bones, number of patients, treatment, and follow up. ${ }^{1}$ EBI Bone Healing System, Zimmer Biomet, Warsaw, IN, USA; ${ }^{2}$ Bone Growth Stimulator, OSSATEC, Uden, The Netherlands; f: frequency; $\Delta \mathrm{t}_{\mathrm{b}}$ : burst width; $\mathrm{f}_{\mathrm{b}}$ : burst repeats; $\Delta \mathrm{t}_{\mathrm{p}}$ : pulse width; OP: surgery; + ELF-PEMF treatment; - placebo treatment; n.s.: not specified; ${ }^{*}$ obtained from a secondary source.

\subsection{ELF-PEMF Treatment to Support Healing of Osteotomies}

Osteotomies causing a defined gap of the bone deserve a discrete consideration. So far, five studies can be cited which investigated ELF-PEMF treatment to support osteotomy healing, in a prospective and blinded way [116-119] (Figure 5). Three studies used an ELF-PEMF with a frequency of $75 \mathrm{~Hz}$ for $8 \mathrm{~h}$ per day, over a time period of 1,2 , or $\geq 23$ months $[116,117,119]$. The fourth study used an ELF-PEMF with a frequency of $15 \mathrm{~Hz}$ for $4 \mathrm{~h}$ per day for more than 1 year during limb lengthening [118]. The fifth study used an ELF-PEMF with a frequency of $16 \mathrm{~Hz}$ for only $7 \mathrm{~min}$ per day for 30 days following high tibial osteotomy [120]. In three studies, commercial ELF-PEMF devices were used, namely EBI stimulator (Electro-Biology Inc, Fairfield, NJ, USA) [118], BIOSTIM@(IGEA S.p.A., Carpi,

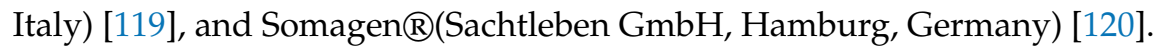

These osteotomy-based studies have the advantage that the patients are highly homogeneous and compliant. However, with an expected $100 \%$ consolidation rate, readout parameters and follow-up time-points require critical attention. Four of the studies measured consolidation rates and/or the time to heal. Three of the studies additionally investigated the ELF-PEMF effect on bone mineral density (BMD). Overall, ELF-PEMF treatment accelerated osteotomy healing, an effect best observed at earlier follow-up time-points. For example, in the study of Borsalino et al., consolidation was significantly advanced (2.6-fold) in the ELF-PEMF group at day 40, but no further changes were observed at day 90 [116]. This was comparable to the study of Mammi et al., where consolidation rates were significantly advanced in the ELF-PEMF group 60 days following surgery [117]. Extrapolating the results of the study from Ziegler et al., consolidation of the osteotomy gap was accelerated by approx. 5 weeks ( $\sim 17 \%$ reduction). This is in line with the study of Luna Gonzalez et al., where ELF-PEMF exposure reduced the time until removal of the external fixator after limb lengthening by approximately 10\% [119]. Furthermore, later follow-up time-points revealed a positive effect of the ELF-PEMF treatment on BMD $[116,118,119]$. This was also observed by Abdelrahim et al., who found 
increased BMD after ELF-PEMF treatment $2 \mathrm{~h}$ per day for 12 days $\left(\Delta \mathrm{t}_{\mathrm{b}}=200 \mathrm{~ns} ; \mathrm{f}_{\mathrm{b}}=72 \mathrm{~Hz}\right.$; peak amplitude intensity $=$ n.s.; $\Delta t_{p}=$ n.s.) in patients with mandibular fractures [121], and Dallari et al., who found increased BMD in patients with hip revision prostheses after ELF-PEMF treatment $6 \mathrm{~h}$ per day for 90 days $\left(\Delta t_{b}=5 \mathrm{~ms} ; \mathrm{f}_{\mathrm{b}}=75 \mathrm{~Hz}\right.$; peak amplitude intensity $=\mathrm{n}$.s.; $\Delta \mathrm{t}_{\mathrm{p}}=5 \mu \mathrm{s}$; generated with the BIOSTIM, IGEA, Carpi, Italy) [122].

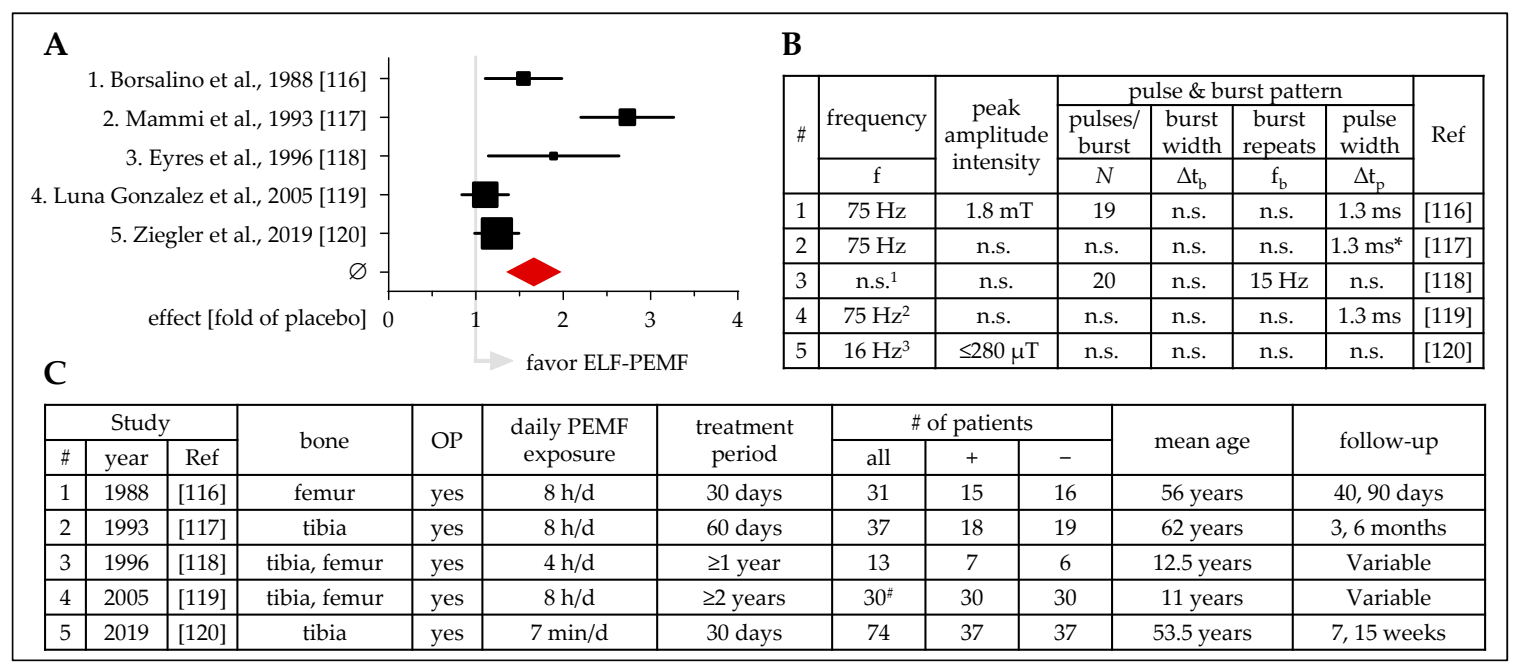

Figure 5. Clinical studies (prospective, placebo-controlled, blinded) investigating the effect of ELF-PEMF treatment on osteotomies. (A) Forest plot showing ELF-PEMF effects fold of placebo $\pm 95 \%$ C.I.-sum was calculated as described by Neyeloff et al. [107], with weighting based on sample size. (B) Overview on the ELF-PEMFs used in the presented studies. (C) Overview on the presented studies including affected bones, number of patients, treatment, and follow up. ${ }^{1}$ device from Electro-Biology Inc, Fairfield, NJ, USA; ${ }^{2}$ BIOSTIM ${ }^{\circledR}$, IGEA S.p.A., Carpi, Italy; ${ }^{3}$ Somagen ${ }^{\circledR}$, Sachtleben GmbH, Hamburg, Germany; f: frequency; $\Delta \mathrm{t}_{\mathrm{b}}$ : burst width; $\mathrm{f}_{\mathrm{b}}$ : burst repeats; $\Delta \mathrm{t}_{\mathrm{p}}$ : pulse width; \# left-right comparison; OP: surgery; + ELF-PEMF treatment; - placebo treatment; n.s.: not specified; * obtained from secondary source.

\subsection{ELF-PEMF Treatment for Osteoporosis}

Three studies investigated the use of ELF-PEMF to treat osteoporosis in a prospective and blinded fashion (Figure 6). These studies used ELF-PEMF with frequencies of $8 \mathrm{~Hz}$ [123], $33 \mathrm{~Hz}$ [124], and $72 \mathrm{~Hz}$ [125]. ELF-PEMF treatment conditions reached from $30 \mathrm{~min}$ per day, 3 days a week for 3 or 6 months up to $10 \mathrm{~h}$ daily for 3 months. Despite the different treatment conditions, ELF-PEMF-treated patients had overall improved BMDs in these studies (mean fold of placebo $=8.62 \pm 3.85$ ). Interestingly, the ELF-PEMF effect was more pronounced when using lower frequencies with shorter treatment duration. This finding is supported by the work of Lui et al., which shows that the positive effect of ELF-PEMF treatment, applied 6 times, 40 min per week for 5 weeks $\left(\Delta t_{b}=0.2 \mathrm{~ms} ; \mathrm{f}_{\mathrm{b}}=8 \mathrm{~Hz}\right.$; peak amplitude intensity $=3.82 \mathrm{mT} ; \Delta \mathrm{t}_{\mathrm{p}}=$ n.s.; generated with a XT-2000B therapeutic stimulator, Tianjin xtmed, Tianjin, China), on BMD is even comparable to alendronate treatment [126]. In addition to the improved BMD, Li et al. reported that ELF-PEMF treatment additionally reduced marrow fat in these patients [123]. 


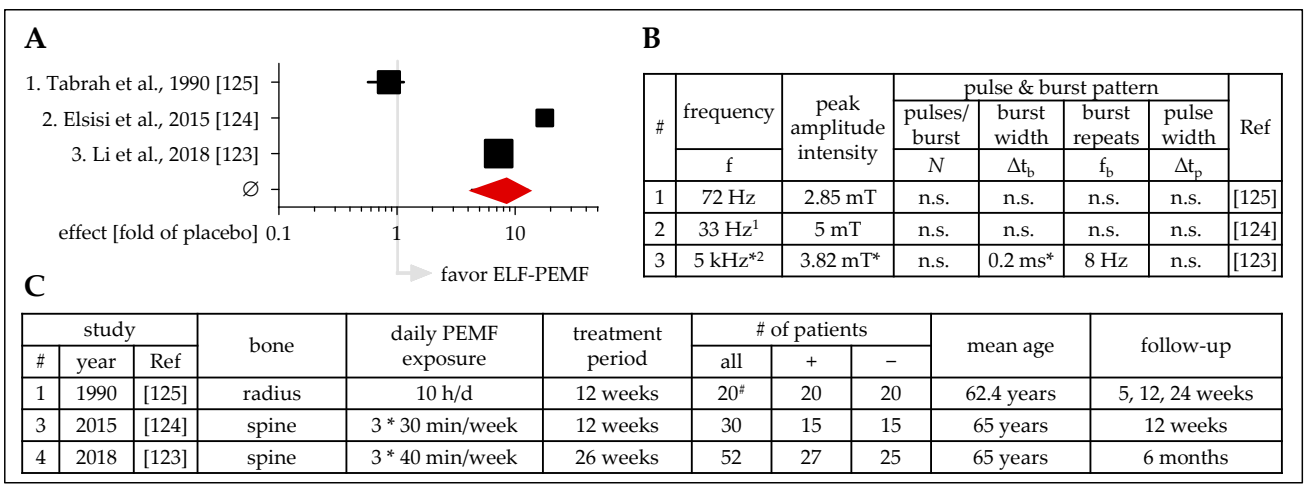

Figure 6. Clinical studies (prospective, placebo-controlled, blinded) investigating the effect of ELF-PEMF treatment on osteoporosis. (A) Forest plot showing ELF-PEMF effects fold of placebo $\pm 95 \%$ C.I.-sum was calculated as described by Neyeloff et al. [107], with weighting based on sample size. (B) Tabular overview of the ELF-PEMF used in the presented studies. (C) Tabular overview of the presented studies including affected bones, basic information on the treatment and follow up, as well as the number of patients investigated. ${ }^{1}$ Automatic PMT Quattro Pro, ASA magnetic field, Arcugnano, Italy; ${ }^{2}$ XT-2000B therapeutic stimulator, Tianjin xtmed, Tianjin, China; f: frequency; $\Delta \mathrm{t}_{\mathrm{b}}$ : burst width; $\mathrm{f}_{\mathrm{b}}$ : burst repeats; $\Delta \mathrm{t}_{\mathrm{p}}$ : pulse width; " left-right comparison; + ELF-PEMF treatment; - placebo treatment; n.s.: not specified; * obtained from a secondary source.

\subsection{ELF-PEMF Treatment after Spinal Fusion}

Up to now, there are four prospective and blinded studies investigating the effect of ELF-PEMF treatment on spinal fusion (Figure 7). While one study does not specify the used ELF-PEMF [127], the other studies use ELF-PEMFs with burst frequencies of $15 \mathrm{~Hz}$ [128-130]. Daily ELF-PEMF exposures ranged from 4 to $8 \mathrm{~h}$ for 30 or 90 days. The patients' mean age ranged from 37.7 to 50.5 years. In summary, these studies favor the use of ELF-PEMF to support spinal fusion (mean OR $=3.40 \pm 1.19$ ). Besides improved spinal fusion, in the study of Omar et al., patients reported pain relief (decrease in VAS (visual analogue scale) score [131]), less disability due to pain (reduced OSW (Oswestry disability index) score [132]), and improved flexion of the lower extremities after ELF-PEMF treatment for $20 \mathrm{~min}$ per day for 3 weeks $\left(\Delta t_{b}=\right.$ n.s.; $f_{b}=4-4000 \mathrm{~Hz}$; peak amplitude intensity $=0.5-1.5 \mathrm{mT} ; \Delta \mathrm{t}_{\mathrm{p}}=\mathrm{n}$.s. $)$ [133].

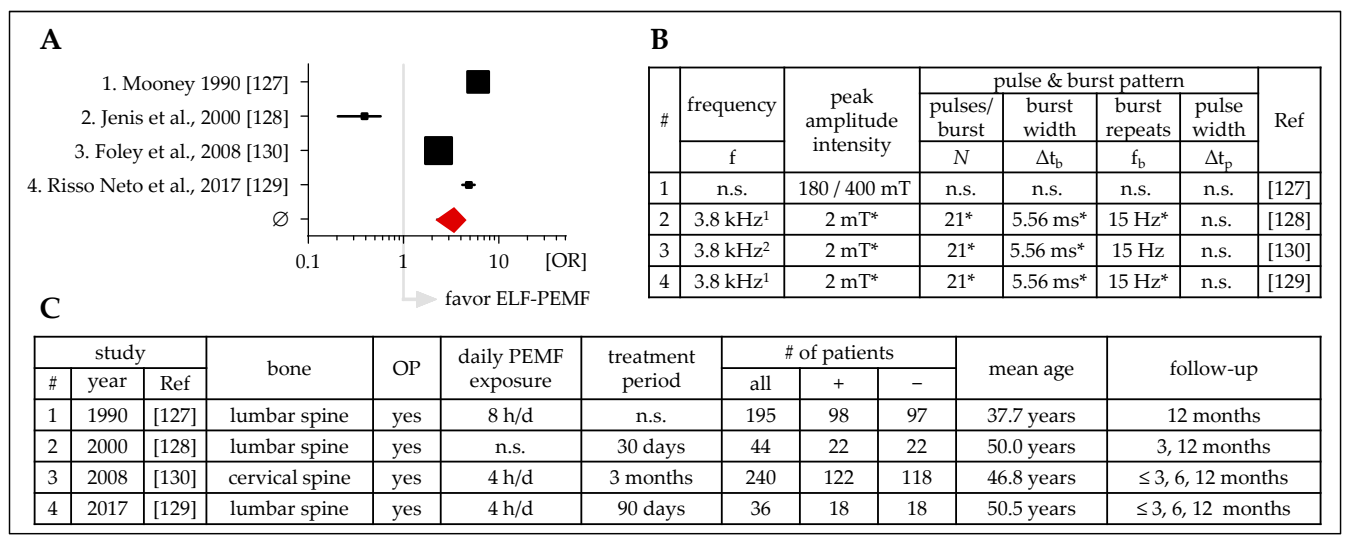

Figure 7. Clinical studies (prospective, placebo-controlled, blinded) investigating the effect of ELF-PEMF treatment on spinal fusion. (A) Forest plot showing OR $\pm 95 \%$ C.I.- sum was calculated as described by Neyeloff et al. [107], with weighting based on sample size. (B) Tabular overview of the ELF-PEMF used in the presented studies. (C) Tabular overview of the presented studies including affected bones, basic information on the treatment and follow up, as well as the number of patients investigated. ${ }^{1}$ Spinal-Stim, Orthofix Inc., McKinney, TX, USA; ${ }^{2}$ Cervical-Stim, Orthofix Inc., McKinney, TX, USA; f: frequency; $\Delta \mathrm{t}_{\mathrm{b}}$ : burst width; $\mathrm{f}_{\mathrm{b}}$ : burst repeats; $\Delta \mathrm{t}_{\mathrm{p}}$ : pulse width; OP: surgery; + ELF-PEMF treatment; - placebo treatment; n.s.: not specified; ${ }^{*}$ obtained from a secondary source. 


\subsection{ELF-PEMF Effects on Osteoarthritis}

Noteworthy, there are 12 prospective and blinded studies investigating ELF-PEMF treatment as a possible adjunct to conservative treatment of osteoarthritis of the knee (Table 1). By using frequencies all over the ELF-PEMF range, these studies conspicuously differ from the studies reported above. Furthermore, treatment duration, which is quite comparable among these studies ( $\leq 1 \mathrm{~h}$ per day for 2 to 6 weeks), is much shorter compared with most studies on bone healing. In contrast to the other studies, which mainly used radiologic endpoints, these studies used different questionnaires for primary outcomes. Pain, for example, was primarily assessed using VAS (visual analog scale) and/or Likert scale [134]. Pain, in association with stiffness was primarily assessed using WOMAC (Western Ontario and McMaster Universities osteoarthritis index) [135], but also KOOS (knee injury and osteoarthritis outcome score) [136], and/or ROM (range of motion) questionnaire [137]. As one of the first of such studies, Trock et al. additionally used a modified Ritchie scale to determine joint tenderness [138]. This or other joint indices represent a good measure to assess joint function and disease progression [139], and thus should be considered for further studies. Limitations in daily life were determined using the EQ-5D (EuroQol-5 Dimension) or OSW (Oswestry disability index) questionnaire $[132,140]$. Sutbeyaz et al. additionally used the NPDS (Northwick Park dependency score) [141] to determine the need for help in daily life [142].

Noteworthy, all studies have in common that ELF-PEMF treatment never negatively affected the reported outcome. However, the reported outcomes differ strongly, ranging from no effect to significant improvement by ELF-PEMF treatment. These great differences can neither be attributed to the patients' age, gender, or BMI, nor the applied ELF-PEMF or treatment duration. However, ELF-PEMF effects seemed to be more pronounced when initial pain and disability levels were high and patients had demonstrable psychological strain. Thus, a possible explanation may be the mainly subjective nature of the primary outcome parameters. Therefore, it is recommended to additionally include more quantifiable measures in future studies.

One attempt was done by Reilingh et al., who investigated effects of ELF-PEMF treatment, applied for $4 \mathrm{~h}$ per day over 60 days $\left(\Delta \mathrm{t}_{\mathrm{b}}=\right.$ n.s.; $\mathrm{f}_{\mathrm{b}}=75 \mathrm{~Hz}$; peak amplitude intensity $=1.5 \mathrm{mT} ; \Delta \mathrm{t}_{\mathrm{p}}=\mathrm{n}$.s.; generated with the I-ONE, IGEA, Carpi, Italy), in patients following arthroscopic debridement and micro-fracture of an osteochondral defect of the talus. In addition to the EQ-5D and the AOFAS (American Orthopaedic Foot and Ankle Society) score, the rate of sport resumption as well as the mean time to sport resumption were assessed. Most likely due to the relatively young mean age ( $\sim 34$ years) and the high activity level of the patients, this study could only detect a trend towards faster resumption to sport in the ELF-PEMF group [143].

This is in line with the study of Cadossi et al., who investigated the effect of ELF-PEMF treatment, applied for $4 \mathrm{~h}$ per day over 60 days $\left(\Delta \mathrm{t}_{\mathrm{b}}=\right.$ n.s.; $\mathrm{f}_{\mathrm{b}}=75 \mathrm{~Hz}$; peak amplitude intensity $=1.5 \mathrm{mT}$; $\Delta t_{p}=$ n.s.; generated with the I-ONE, IGEA, Carpi, Italy), in patients with osteochondral defects of the talus who received bone marrow-derived cell transplantation in the defect area. In this study, ELF-PEMF treatment did not affect the immediate outcome 30 days after surgery. However, patients in the ELF-PEMF group scored significantly better at the VAS and AOFAS scores than patients in the placebo group at the later follow-up time-points (2, 6, and 12 months) [144]. 
Table 1. Clinical studies (prospective, placebo-controlled, blinded) investigating the effect of ELF-PEMF treatment on osteoarthritis of the knee (adjunct to conservative treatment).

\begin{tabular}{|c|c|c|c|c|c|c|c|c|c|c|c|c|c|c|c|c|}
\hline \multirow[b]{2}{*}{ \# } & \multirow[b]{2}{*}{ Year } & \multirow[b]{2}{*}{ Ref } & \multirow{2}{*}{$\begin{array}{c}\text { Frequency } \\
\mathrm{f}\end{array}$} & \multirow{2}{*}{$\begin{array}{c}\text { Peak } \\
\text { Amplitude } \\
\text { Intensity }\end{array}$} & \multirow{2}{*}{$\begin{array}{l}\text { Pulse \& Burst } \\
\text { Pattern }\end{array}$} & \multirow{2}{*}{$\begin{array}{l}\text { Daily PEMF } \\
\text { Exposure }\end{array}$} & \multirow[b]{2}{*}{ Treatment Period } & \multirow[b]{2}{*}{ All } & \multirow[b]{2}{*}{+} & \multirow[b]{2}{*}{-} & \multirow[b]{2}{*}{ Mean Age } & \multirow[b]{2}{*}{ Follow-Up } & \multicolumn{4}{|c|}{ Compared to Placebo } \\
\hline & & & & & & & & & & & & & Pain & Stiffness & Mobility & $\begin{array}{l}\text { Quality of } \\
\text { Life }\end{array}$ \\
\hline 1 & 1993 & [145] & $5-12 \mathrm{~Hz}$ & n.s. & n.s. & $4.5 * 30 \mathrm{~min} /$ week & 4 weeks & 25 & 13 & 12 & $\geq 60$ years & $2,4,8$ weeks & \begin{tabular}{l} 
VAS \} $\\
{\text { motion \} }\end{array}} &{\text { n.s. }} &{\text { n.s. }} &{\text { n.s. }} \\
{\hline 2} &{1994} &{\text { [138] }} &{5-12 \mathrm{~Hz}} &{\text { n.s. }} &{\text { n.s. }} &{4.5 * 30 \mathrm{~min} / \text { week }} &{4 \text { weeks }} &{86} &{42} &{44} &{67 \text { years }} &{2,4,8 \text { weeks }} &{\begin{array}{l}\text { VAS \} } \\
{\text { motion \} }\end{array}} &{\text { n.s. }} &{\text { n.s. }} &{\text { n.s. }} \\
{\hline 4} &{2001} &{\text { [146] }} &{3,7.8,20 \mathrm{~Hz}^{1}} &{<50 \mu \mathrm{T}} &{\text { n.s. }} &{3 * 10 \mathrm{~min} / \mathrm{d}} &{6 \text { weeks }} &{69} &{34} &{35} &{63 \text { years }} &{2,4,6 \text { weeks }} &{\text { WOMAC \ }} &{\text { WOMAC \ }} &{\text { WOMAC \ }} &{\text { EQ-5D } \nearrow} \\
{\hline 5} &{2005} &{\text { [147] }} &{50 \mathrm{~Hz}^{2}} &{\text { n.s. }} &{\Delta \mathrm{t}_{\mathrm{p}}=6 \mathrm{~ms}} &{5 * 2 \mathrm{~h} / \text { week }} &{6 \text { weeks }} &{83} &{42} &{41} &{60 \text { years }} &{\text { 2, } 12 \text { weeks }} &{\text { WOMAC }=} &{\text { WOMAC \ }} &{\text { WOMAC }=} &{\text { n.s. }} \\
{\hline 6} &{2005} &{\text { [148] }} &{10-300 \mathrm{~Hz}} &{13.6 \mu \mathrm{T}} &{\text { n.s. }} &{16 \mathrm{~min} / \mathrm{d}} &{6 \text { weeks }} &{71} &{35} &{36} &{60.2 \text { years }} &{6 \text { weeks }} &{\text { KSS \ }} &{\text { KSS】 }} &{\text { KSS】 }} &{\text { n.s. }} \\
{\hline 7} &{2006} &{\text { [149] }} &{5 \mathrm{~Hz} / 10 \mathrm{~Hz}^{3}} &{1.3-2.1 \mathrm{~T}} &{\Delta \mathrm{t}_{\mathrm{p}}=270 \mu \mathrm{s}} &{3 * 15 \mathrm{~min} / \text { week }} &{3 \text { weeks }} &{36} &{17} &{19} &{74,5 \text { years }} &{3,4,7 \text { weeks }} &{\text { NRS \ }} &{\text { OSW \} } &{\text { OSW \} } &{\text { n.s. }} \\
{\hline 8} &{2006} &{\text { [142] }} &{0.1-64 \mathrm{~Hz}^{4}} &{\text { n.s. }} &{\text { n.s. }} &{2 * 30 \mathrm{~min} / \mathrm{d}} &{3 \text { weeks }} &{32} &{17} &{15} &{42.5 \text { years }} &{3 \text { weeks }} &{\text { VAS \} } &{\operatorname{ROM} \nearrow} &{\text { mobility } \nearrow} &{\text { NPDS \ }} \\
{\hline 9} &{2009} &{\text { [150] }} &{50 \mathrm{~Hz}^{4}} &{105 \mu \mathrm{T}} &{\text { n.s. }} &{5 * 30 \mathrm{~min} / \text { week }} &{3 \text { weeks }} &{55} &{30} &{25} &{58 \text { years }} &{3 \text { weeks }} &{\begin{array}{c}\text { VAS }= \\
\text { Likert }=\end{array}} &{\begin{array}{c}\text { Lequesne = } \\
\text { ROM = }\end{array}} &{\text { Lequesne }=} &{\text { n.s. }} \\
{\hline 10} &{2010} &{\text { [151] }} &{50 \mathrm{~Hz}^{5}} &{3 \mathrm{mT}} &{\mathrm{T}_{\mathrm{b}}=90 \mathrm{~s}} &{5 * 30 \mathrm{~min} / \text { week }} &{2 \text { weeks }} &{40} &{20} &{20} &{61.3 \text { years }} &{2 \text { weeks }} &{\begin{array}{c}\text { VAS }= \\
\text { WOMAC = }\end{array}} &{\text { WOMAC }=} &{\text { WOMAC = }} &{\text { n.s. }} \\
{\hline 11} &{2013} &{\text { [152] }} &{\begin{array}{l}6-100 \mathrm{~Hz}^{6} \\
(0.1-3 \mathrm{kHz}) \\
\end{array}} &{\text { n.s. }} &{\text { n.s. }} &{3 * 20 \mathrm{~min} / \text { week }} &{6 \text { weeks }} &{28^{\#}} &{28} &{28} &{69.9 \text { years }} &{3 \text { months }} &{\text { 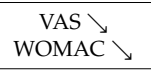 }} &{\begin{array}{c}\text { WOMAC \} } \\
{\text { ROM } \nearrow} & \text { WOMAC \ } & \text { n.s. } \\
\hline 12 & 2016 & \text { [153] } & 50 \mathrm{~Hz}^{7} & 100 \mu \mathrm{T} & \text { n.s. } & 5 * 60 \mathrm{~min} / \text { week } & 4 \text { weeks } & 29 & 14 & 15 & 57.2 \text { years } & 4 \text { weeks } & \begin{array}{c}\text { VAS }= \\
\text { WOMAC = }\end{array} & \text { WOMAC = } & \text { WOMAC = } & \text { n.s. } \\
\hline\end{array}\end{array}$
\end{tabular}
\end{tabular}

${ }^{1}$ Medicur, Snowden Healthcare, Nottingham, UK; ${ }^{2}$ pulse generator, Biofields Aps, Copenhagen, Denmark; ${ }^{3}$ CR-3000 system, CR Technology Co., Kyungki-do, Korea; ${ }^{4}$ wave ranger professional, MRS 2000+Home, Eschen, Germany; ${ }^{5}$ Energy Plus Roland Serie, Elettronica Pagani, Milan, Italy; ${ }^{6}$ Magnetofield device, F\&B International, Parma, Italy; ${ }^{7}$ Automatic PMT Quattro Pro, ASA magnetic field, Arcugnano, Italy; \# left-right comparison; + ELF-PEMF treatment; - placebo treatment; $n . s .:$ not specified; $\Delta \mathrm{t}_{\mathrm{p}}$ : pulse width; $\mathrm{T}_{\mathrm{b}}$ : burst repetition period; $\nearrow$ increased; \ decreased; = comparable; ROM: range of motion; VAS: visual analogue scale; WOMAC: Western Ontario and McMaster Universities osteoarthritis index; EQ-5D: EuroQol-5 Dimension; OSW: Oswestry disability index; NPDS: Northwick Park dependency score. 


\section{Conclusions}

Our review clearly shows that ELF-PEMFs represent a valuable adjunct to conventional therapy for bone and osteochondral defects. However, treatment modalities have to be better defined in order to establish ELF-PEMF treatment in the clinical routine. Adjustment of the ELF-PEMF treatment conditions to specific indications (patients at high risk for complications, e.g., elderly, diabetics, smokers, etc.) and even phases of bone healing, which includes ELF-PEMF parameters (e.g. frequencies, intensities, pulse, and burst pattern, etc.), the way of application, as well as the frequency and the duration of the application are feasible. However, our understanding of the underlying mechanisms is still poor, which contributed to the fact that ELF-PEMF treatment to support bone healing and function could not be established in the clinical routine yet [154]. To accomplish this aim, in vitro research investigating the underlying mechanisms requires more holistic/comprehensive cell model approaches (e.g., three dimensional (3D) co-culture models) with sound parameter control resembling the in vivo situation in diseased or fractured bone. Only if the underlying mechanisms are better understood and this knowledge can be translated into the clinic, an indication-oriented treatment regimen using ELF-PEMFs will become a feasible therapeutic option. Therefore, more systematic studies are absolutely essential to unravel optimal treatment conditions.

\section{Search Strategy}

On the 18th of June 2019, a search was performed with PubMed and Web of Science. The search strategy is summarized in Table 2.

Table 2. Search strategy.

\begin{tabular}{|c|c|c|c|c|}
\hline & Search Terms & $\overline{A l l}$ & Reviews & Clinical \\
\hline 1 & "PEMF" or "pulsed electromagnetic" and "bone" & 554 & 70 & 45 \\
\hline 2 & "PEMF" or "pulsed electromagnetic" and "osteopenia" & 56 & 9 & 11 \\
\hline 3 & "PEMF" or "pulsed electromagnetic" and "osteoporosis" & 85 & 12 & 11 \\
\hline 4 & "PEMF" or "pulsed electromagnetic" and "osteomalacia" & 0 & 0 & 0 \\
\hline 5 & "PEMF" or "pulsed electromagnetic" and "fracture" & 230 & 40 & 22 \\
\hline 6 & "PEMF" or "pulsed electromagnetic" and "non-union" & 14 & 1 & 2 \\
\hline 7 & "PEMF" or "pulsed electromagnetic" and "pseudarthrosis" & 29 & 5 & 4 \\
\hline 8 & "PEMF" or "pulsed electromagnetic" and "osteolysis" & 5 & 0 & 0 \\
\hline 9 & "PEMF" or "pulsed electromagnetic" and "osteoarthritis" & 83 & 22 & 22 \\
\hline 10 & "PEMF" or "pulsed electromagnetic" and "osteogenesis" & 124 & 10 & 4 \\
\hline 11 & "PEMF" or "pulsed electromagnetic" and "osteogenic" & 67 & 2 & 1 \\
\hline 12 & "PEMF" or "pulsed electromagnetic" and "MSC" & 17 & 3 & 0 \\
\hline 13 & $\begin{array}{c}\text { "PEMF" or "pulsed electromagnetic" and "mesenchymal * } \\
\text { cells" }\end{array}$ & 70 & 3 & 1 \\
\hline 14 & "PEMF" or "pulsed electromagnetic" and "osteoblast" & 124 & 6 & 0 \\
\hline 15 & "PEMF" or "pulsed electromagnetic" and "osteocyte" & 9 & 1 & 0 \\
\hline 16 & $\begin{array}{l}\text { "PEMF" or "pulsed electromagnetic" and } \\
\text { "osteoclastogenesis" }\end{array}$ & 130 & 11 & 4 \\
\hline 17 & "PEMF" or "pulsed electromagnetic" and "osteoclast" & 34 & 2 & 0 \\
\hline \multicolumn{2}{|r|}{ Sum } & 1631 & 197 & 127 \\
\hline \multicolumn{2}{|r|}{ Removal of Duplicates } & 692 & 93 & 68 \\
\hline \multicolumn{2}{|r|}{ plus Manuscripts from other sources } & 710 & 97 & 81 \\
\hline
\end{tabular}

PEMF: pulsed electromagnetic fields. MSC: mesenchymal stem cells.

Considering only manuscripts in English or German language, a total of 662 manuscripts remained for further screening. In Figure 8, the number of papers published per year is presented. 


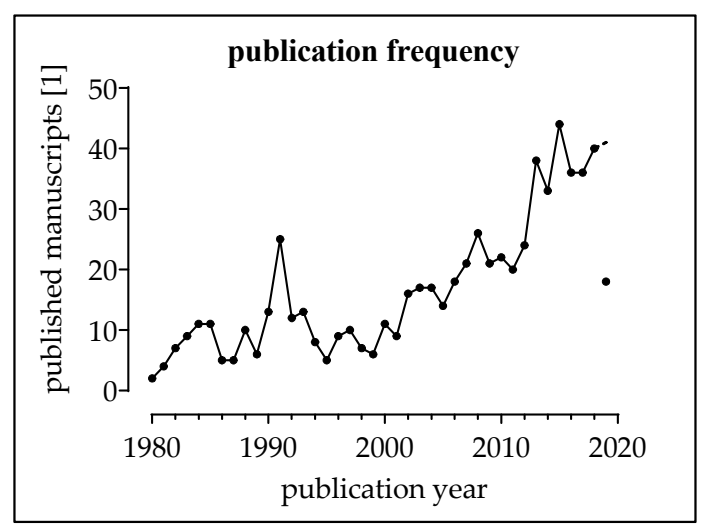

Figure 8. Number of publications published per year with the used (Table 2) search terms.

Author Contributions: Conceptualization, S.E.; literature research S.E. and K.F.; literature review S.E., S.S., R.H.A.-W., W.E., K.F. and M.R.; analysis, S.E.; writing-original draft preparation, S.E.; writing-review and editing, S.S., R.H.A.-W., W.E., K.F., M.R. and A.K.N.; visualization, S.E. and M.R.; supervision, A.K.N.

Funding: This research received no external funding.

Acknowledgments: We'd like to thank Niklas Erdmann for assistance: We acknowledge support from the Deutsche Forschungsgemeinschaft and Open Access Publishing Fund of University of Tübingen.

Conflicts of Interest: The authors declare no conflict of interest.

\section{Abbreviations}

$\begin{array}{ll}\text { ALP } & \text { alkaline phosphatase } \\ \text { BMD } & \text { bone mineral density } \\ \text { BMP } & \text { bone morphogenetic protein } \\ \text { COL } & \text { collagen } \\ \text { ECM } & \text { extracellular matrix } \\ \text { ELF } & \text { extremely low frequency } \\ \text { ELF-PEMF } & \text { extremely low frequency pulsed electromagnetic field } \\ \text { ELF-REMF } & \text { extremely low frequency rectangular electromagnetic field } \\ \text { ELF-SEMF } & \text { extremely low frequency sinusoidal electromagnetic field } \\ \text { ELF-TEMF } & \text { extremely low frequency triangular electromagnetic field } \\ \text { FN } & \text { fibronectin } \\ \text { KOOS } & \text { knee injury and osteoarthritis outcome score } \\ \text { MMP } & \text { matrix metalloproteinase } \\ \text { NPDS } & \text { Northwick Park dependency score } \\ \text { OP } & \text { surgery } \\ \text { OR } & \text { Odds Ratio } \\ \text { OSW } & \text { Oswestry disability index } \\ \text { ROM } & \text { range of motion } \\ \text { ROS } & \text { reactive oxygen species } \\ \text { TGF- } \beta & \text { transforming growth factor beta } \\ \text { UV } & \text { ultraviolet } \\ \text { VAS } & \text { visual analogue scale } \\ \text { VLF } & \text { very low frequency } \\ \text { WOMAC } & \text { Western Ontario and McMaster Universities osteoarthritis index }\end{array}$

\section{References}

1. Frost, H.M. Wolff's law and bone's structural adaptations to mechanical usage: An overview for clinicians. Angle Orthod. 1994, 64, 175-188. 
2. Friedenberg, Z.B.; Brighton, C.T. Bioelectric potentials in bone. J. Bone Jt. Surg. Am. 1966, 48, 915-923. [CrossRef]

3. Bassett, C.A.; Pawluk, R.J.; Becker, R.O. Effects of electric currents on bone in vivo. Nature 1964, $204,652-654$. [CrossRef] [PubMed]

4. Bassett, C.A.; Becker, R.O. Generation of electric potentials by bone in response to mechanical stress. Science 1962, 137, 1063-1064. [CrossRef] [PubMed]

5. Ahn, A.C.; Grodzinsky, A.J. Relevance of collagen piezoelectricity to "wolff's law": A critical review. Med. Eng. Phys. 2009, 31, 733-741. [CrossRef] [PubMed]

6. Pienkowski, D.; Pollack, S.R. The origin of stress-generated potentials in fluid-saturated bone. J. Orthop. Res. 1983, 1, 30-41. [CrossRef]

7. Dunn, A.W.; Rush, G.A., 3rd. Electrical stimulation in treatment of delayed union and nonunion of fractures and osteotomies. South. Med. J. 1984, 77, 1530-1534. [CrossRef]

8. Bassett, C.A. The development and application of pulsed electromagnetic fields (pemfs) for ununited fractures and arthrodeses. Orthop. Clin. N. Am. 1984, 15, 61-87.

9. Kort, J.S.; Schink, M.M.; Mitchell, S.N.; Bassett, C.A. Congenital pseudoarthrosis of the tibia: Treatment with pulsing electromagnetic fields. Clin. Orthop. Relat. Res. 1982, 165, 124-137.

10. Bassett, C.A.; Caulo, N.; Kort, J. Congenital "pseudarthroses" of the tibia: Treatment with pulsing electromagnetic fields. Clin. Orthop. Relat. Res. 1981, 154, 136-148. [CrossRef]

11. Goodman, R.; Shirley-Henderson, A. Exposure of cells to extremely low-frequency electromagnetic fields: Relationship to malignancy? Cancer Cells 1990, 2, 355-359.

12. Binhi, V.N.; Savin, A.V. Molecular gyroscopes and biological effects of weak extremely low-frequency magnetic fields. Phys. Rev. E 2002, 65, 051912. [CrossRef]

13. Muehsam, D.J.; Pilla, A.A. A lorentz model for weak magnetic field bioeffects: Part I-Thermal noise is an essential component of ac/dc effects on bound ion trajectory. Bioelectromagnetics 2009, 30, 462-475. [CrossRef]

14. Muehsam, D.J.; Pilla, A.A. A lorentz model for weak magnetic field bioeffects: Part II-Secondary transduction mechanisms and measures of reactivity. Bioelectromagnetics 2009, 30, 476-488. [CrossRef]

15. Blank, M.; Goodman, R. DNA is a fractal antenna in electromagnetic fields. Int. J. Radiat. Biol. 2011, 87, 409-415. [CrossRef]

16. Foley, L.E.; Gegear, R.J.; Reppert, S.M. Human cryptochrome exhibits light-dependent magnetosensitivity. Nat. Commun. 2011, 2, 356. [CrossRef]

17. Bawin, S.M.; Kaczmarek, L.K.; Adey, W.R. Effects of modulated vhf fields on the central nervous system. Ann. N. Y. Acad. Sci. 1975, 247, 74-81. [CrossRef]

18. Heilbrunn, L.V. The electrical charges of living cells. Science 1925, 61, 236-237. [CrossRef]

19. Pchelintseva, E.; Djamgoz, M.B.A. Mesenchymal stem cell differentiation: Control by calcium-activated potassium channels. J. Cell. Physiol. 2018, 233, 3755-3768. [CrossRef]

20. Pall, M.L. Electromagnetic fields act via activation of voltage-gated calcium channels to produce beneficial or adverse effects. J. Cell. Mol. Med. 2013, 17, 958-965. [CrossRef]

21. Cui, Y.; Liu, X.; Yang, T.; Mei, Y.A.; Hu, C. Exposure to extremely low-frequency electromagnetic fields inhibits t-type calcium channels via aa/lte4 signaling pathway. Cell Calcium 2014, 55, 48-58. [CrossRef]

22. Wertheimer, N.; Leeper, E. Electrical wiring configurations and childhood cancer. Am. J. Epidemiol. 1979, 109, 273-284. [CrossRef] [PubMed]

23. Friedman, J.; Kraus, S.; Hauptman, Y.; Schiff, Y.; Seger, R. Mechanism of short-term erk activation by electromagnetic fields at mobile phone frequencies. Biochem. J. 2007, 405, 559-568. [CrossRef]

24. Ehnert, S.; Fentz, A.K.; Schreiner, A.; Birk, J.; Wilbrand, B.; Ziegler, P.; Reumann, M.K.; Wang, H.; Falldorf, K.; Nussler, A.K. Extremely low frequency pulsed electromagnetic fields cause antioxidative defense mechanisms in human osteoblasts via induction of *o2(-) and h2o2. Sci. Rep. 2017, 7, 14544. [CrossRef] [PubMed]

25. Blank, M.; Goodman, R. Electromagnetic fields stress living cells. Pathophysiology 2009, 16, 71-78. [CrossRef] [PubMed]

26. Chang, K.; Chang, W.H.; Tsai, M.T.; Shih, C. Pulsed electromagnetic fields accelerate apoptotic rate in osteoclasts. Connect. Tissue Res. 2006, 47, 222-228. [CrossRef]

27. Tang, Q.; Zhao, N. Effects of low frequency electromagnetic fields on osteoblasts proliferation and cell cycle. Chin. Sci. Bull. 1999, 44, 2174-2177. [CrossRef] 
28. Mates, J.M.; Perez-Gomez, C.; Nunez de Castro, I. Antioxidant enzymes and human diseases. Clin. Biochem. 1999, 32, 595-603. [CrossRef]

29. Raggi, F.; Vallesi, G.; Rufini, S.; Gizzi, S.; Ercolani, E.; Rossi, R. Elf magnetic therapy and oxidative balance. Electromagn. Biol. Med. 2008, 27, 325-339. [CrossRef]

30. Zhang, X.; Zhang, J.; Qu, X.; Wen, J. Effects of different extremely low-frequency electromagnetic fields on osteoblasts. Electromagn. Biol. Med. 2007, 26, 167-177. [CrossRef]

31. Zhou, J.; Wang, J.Q.; Ge, B.F.; Ma, X.N.; Ma, H.P.; Xian, C.J.; Chen, K.M. Different electromagnetic field waveforms have different effects on proliferation, differentiation and mineralization of osteoblasts in vitro. Bioelectromagnetics 2014, 35, 30-38. [CrossRef] [PubMed]

32. Ehnert, S.; Falldorf, K.; Fentz, A.K.; Ziegler, P.; Schroter, S.; Freude, T.; Ochs, B.G.; Stacke, C.; Ronniger, M.; Sachtleben, J.; et al. Primary human osteoblasts with reduced alkaline phosphatase and matrix mineralization baseline capacity are responsive to extremely low frequency pulsed electromagnetic field exposure-Clinical implication possible. Bone Rep. 2015, 3, 48-56. [CrossRef] [PubMed]

33. Wei, Y.; Xiaolin, H.; Tao, S. Effects of extremely low-frequency-pulsed electromagnetic field on different-derived osteoblast-like cells. Electromagn. Biol. Med. 2008, 27, 298-311. [CrossRef] [PubMed]

34. Bique, A.M.; Kaivosoja, E.; Mikkonen, M.; Paulasto-Krockel, M. Choice of osteoblast model critical for studying the effects of electromagnetic stimulation on osteogenesis in vitro. Electromagn. Biol. Med. 2016, 35, 353-364. [CrossRef] [PubMed]

35. Kaivosoja, E.; Sariola, V.; Chen, Y.; Konttinen, Y.T. The effect of pulsed electromagnetic fields and dehydroepiandrosterone on viability and osteo-induction of human mesenchymal stem cells. J. Tissue Eng. Regen. Med. 2015, 9, 31-40. [CrossRef] [PubMed]

36. Yamaguchi, D.T.; Huang, J.; Ma, D.; Wang, P.K. Inhibition of gap junction intercellular communication by extremely low-frequency electromagnetic fields in osteoblast-like models is dependent on cell differentiation. J. Cell. Physiol. 2002, 190, 180-188. [CrossRef] [PubMed]

37. Lohmann, C.H.; Schwartz, Z.; Liu, Y.; Li, Z.; Simon, B.J.; Sylvia, V.L.; Dean, D.D.; Bonewald, L.F.; Donahue, H.J.; Boyan, B.D. Pulsed electromagnetic fields affect phenotype and connexin 43 protein expression in mlo-y 4 osteocyte-like cells and ros 17/2.8 osteoblast-like cells. J. Orthop. Res. 2003, 21, 326-334. [CrossRef]

38. Tong, J.; Sun, L.; Zhu, B.; Fan, Y.; Ma, X.; Yu, L.; Zhang, J. Pulsed electromagnetic fields promote the proliferation and differentiation of osteoblasts by reinforcing intracellular calcium transients. Bioelectromagnetics 2017, 38, 541-549. [CrossRef]

39. Zhou, P.; He, F.; Han, Y.; Liu, B.; Wei, S. Nanosecond pulsed electric field induces calcium mobilization in osteoblasts. Bioelectrochemistry 2018, 124, 7-12. [CrossRef]

40. Wu, S.; Yu, Q.; Lai, A.; Tian, J. Pulsed electromagnetic field induces ca(2+)-dependent osteoblastogenesis in c3h10t1/2 mesenchymal cells through the wnt-ca(2+)/wnt-beta-catenin signaling pathway. Biochem. Biophys. Res. Commun. 2018, 503, 715-721. [CrossRef]

41. Hanna, H.; Andre, F.M.; Mir, L.M. Electrical control of calcium oscillations in mesenchymal stem cells using microsecond pulsed electric fields. Stem Cell Res. Ther. 2017, 8, 91. [CrossRef] [PubMed]

42. Spadaro, J.A.; Bergstrom, W.H. In vivo and in vitro effects of a pulsed electromagnetic field on net calcium flux in rat calvarial bone. Calcif. Tissue Int. 2002, 70, 496-502. [CrossRef] [PubMed]

43. Galli, C.; Pedrazzi, G.; Guizzardi, S. The cellular effects of pulsed electromagnetic fields on osteoblasts: A review. Bioelectromagnetics 2019, 40, 211-233. [CrossRef] [PubMed]

44. Itoh, S.; Udagawa, N.; Takahashi, N.; Yoshitake, F.; Narita, H.; Ebisu, S.; Ishihara, K. A critical role for interleukin-6 family-mediated stat3 activation in osteoblast differentiation and bone formation. Bone 2006, 39, 505-512. [CrossRef] [PubMed]

45. Kawamura, N.; Kugimiya, F.; Oshima, Y.; Ohba, S.; Ikeda, T.; Saito, T.; Shinoda, Y.; Kawasaki, Y.; Ogata, N.; Hoshi, K.; et al. Akt1 in osteoblasts and osteoclasts controls bone remodeling. PLoS ONE 2007, 2, e1058. [CrossRef] [PubMed]

46. Mukherjee, A.; Rotwein, P. Akt promotes bmp2-mediated osteoblast differentiation and bone development. J. Cell Sci. 2009, 122, 716-726. [CrossRef]

47. Sollazzo, V.; Palmieri, A.; Pezzetti, F.; Massari, L.; Carinci, F. Effects of pulsed electromagnetic fields on human osteoblastlike cells (mg-63): A pilot study. Clin. Orthop. Relat. Res. 2010, 468, 2260-2277. [CrossRef] 
48. Xie, Y.F.; Shi, W.G.; Zhou, J.; Gao, Y.H.; Li, S.F.; Fang, Q.Q.; Wang, M.G.; Ma, H.P.; Wang, J.F.; Xian, C.J.; et al. Pulsed electromagnetic fields stimulate osteogenic differentiation and maturation of osteoblasts by upregulating the expression of bmprii localized at the base of primary cilium. Bone 2016, 93, 22-32. [CrossRef]

49. Yang, H.J.; Kim, R.Y.; Hwang, S.J. Pulsed electromagnetic fields enhance bone morphogenetic protein-2 dependent-bone regeneration. Tissue Eng. Part A 2015, 21, 2629-2637. [CrossRef] [PubMed]

50. Okada, M.; Kim, J.H.; Yoon, S.T.; Hutton, W.C. Pulsed electromagnetic field (pemf) plus bmp-2 upregulates intervertebral disc-cell matrix synthesis more than either bmp-2 alone or pemf alone. J. Spinal Disord. Tech. 2013, 26, E221-E226. [CrossRef]

51. Schwartz, Z.; Simon, B.J.; Duran, M.A.; Barabino, G.; Chaudhri, R.; Boyan, B.D. Pulsed electromagnetic fields enhance bmp-2 dependent osteoblastic differentiation of human mesenchymal stem cells. J. Orthop. Res. 2008, 26, 1250-1255. [CrossRef] [PubMed]

52. Selvamurugan, N.; Kwok, S.; Vasilov, A.; Jefcoat, S.C.; Partridge, N.C. Effects of bmp-2 and pulsed electromagnetic field (pemf) on rat primary osteoblastic cell proliferation and gene expression. J. Orthop. Res. 2007, 25, 1213-1220. [CrossRef] [PubMed]

53. Aaron, R.K.; Wang, S.; Ciombor, D.M. Upregulation of basal tgfbeta1 levels by emf coincident with chondrogenesis-Implications for skeletal repair and tissue engineering. J. Orthop. Res. 2002, 20, $233-240$. [CrossRef]

54. Yang, X.; He, H.; Gao, Q.; He, C. Pulsed electromagnetic field improves subchondral bone microstructure in knee osteoarthritis rats through a wnt/beta-catenin signaling-associated mechanism. Bioelectromagnetics 2018, 39, 89-97. [CrossRef]

55. Zhai, M.; Jing, D.; Tong, S.; Wu, Y.; Wang, P.; Zeng, Z.; Shen, G.; Wang, X.; Xu, Q.; Luo, E. Pulsed electromagnetic fields promote in vitro osteoblastogenesis through a wnt/beta-catenin signaling-associated mechanism. Bioelectromagnetics 2016, 37, 152-162. [CrossRef]

56. Lin, C.C.; Lin, R.W.; Chang, C.W.; Wang, G.J.; Lai, K.A. Single-pulsed electromagnetic field therapy increases osteogenic differentiation through wnt signaling pathway and sclerostin downregulation. Bioelectromagnetics 2015, 36, 494-505. [CrossRef]

57. Jing, D.; Li, F.; Jiang, M.; Cai, J.; Wu, Y.; Xie, K.; Wu, X.; Tang, C.; Liu, J.; Guo, W.; et al. Pulsed electromagnetic fields improve bone microstructure and strength in ovariectomized rats through a wnt/lrp5/beta-catenin signaling-associated mechanism. PLoS ONE 2013, 8, e79377. [CrossRef]

58. Zhou, J.; He, H.; Yang, L.; Chen, S.; Guo, H.; Xia, L.; Liu, H.; Qin, Y.; Liu, C.; Wei, X.; et al. Effects of pulsed electromagnetic fields on bone mass and wnt/beta-catenin signaling pathway in ovariectomized rats. Arch. Med. Res. 2012, 43, 274-282. [CrossRef]

59. Wheway, G.; Nazlamova, L.; Hancock, J.T. Signaling through the primary cilium. Front. Cell Dev. Biol. 2018, 6, 8. [CrossRef]

60. Pala, R.; Alomari, N.; Nauli, S.M. Primary cilium-dependent signaling mechanisms. Int. J. Mol. Sci. 2017, 18, 2272. [CrossRef]

61. Wang, P.; Tang, C.; Wu, J.; Yang, Y.; Yan, Z.; Liu, X.; Shao, X.; Zhai, M.; Gao, J.; Liang, S.; et al. Pulsed electromagnetic fields regulate osteocyte apoptosis, rankl/opg expression, and its control of osteoclastogenesis depending on the presence of primary cilia. J. Cell. Physiol. 2019, 234, 10588-10601. [CrossRef] [PubMed]

62. Yan, J.L.; Zhou, J.; Ma, H.P.; Ma, X.N.; Gao, Y.H.; Shi, W.G.; Fang, Q.Q.; Ren, Q.; Xian, C.J.; Chen, K.M. Pulsed electromagnetic fields promote osteoblast mineralization and maturation needing the existence of primary cilia. Mol. Cell. Endocrinol. 2015, 404, 132-140. [CrossRef] [PubMed]

63. Manolagas, S.C. From estrogen-centric to aging and oxidative stress: A revised perspective of the pathogenesis of osteoporosis. Endocr. Rev. 2010, 31, 266-300. [CrossRef] [PubMed]

64. Pi, Y.; Liang, H.; Yu, Q.; Yin, Y.; Xu, H.; Lei, Y.; Han, Z.; Tian, J. Lowfrequency pulsed electromagnetic field inhibits ranklinduced osteoclastic differentiation in raw264.7 cells by scavenging reactive oxygen species. Mol. Med. Rep. 2019, 19, 4129-4136.

65. Zhang, J.; Xu, H.; Han, Z.; Chen, P.; Yu, Q.; Lei, Y.; Li, Z.; Zhao, M.; Tian, J. Pulsed electromagnetic field inhibits rankl-dependent osteoclastic differentiation in raw264.7 cells through the ca(2+)-calcineurin-nfatc1 signaling pathway. Biochem. Biophys. Res. Commun. 2017, 482, 289-295. [CrossRef]

66. Lei, Y.; Su, J.; Xu, H.; Yu, Q.; Zhao, M.; Tian, J. Pulsed electromagnetic fields inhibit osteoclast differentiation in raw264.7 macrophages via suppression of the protein kinase b/mammalian target of rapamycin signaling pathway. Mol. Med. Rep. 2018, 18, 447-454. [CrossRef] 
67. He, Z.; Selvamurugan, N.; Warshaw, J.; Partridge, N.C. Pulsed electromagnetic fields inhibit human osteoclast formation and gene expression via osteoblasts. Bone 2018, 106, 194-203. [CrossRef] [PubMed]

68. Tschon, M.; Veronesi, F.; Contartese, D.; Sartori, M.; Martini, L.; Vincenzi, F.; Ravani, A.; Varani, K.; Fini, M. Effects of pulsed electromagnetic fields and platelet rich plasma in preventing osteoclastogenesis in an in vitro model of osteolysis. J. Cell. Physiol. 2018, 233, 2645-2656. [CrossRef]

69. Catalano, A.; Loddo, S.; Bellone, F.; Pecora, C.; Lasco, A.; Morabito, N. Pulsed electromagnetic fields modulate bone metabolism via rankl/opg and wnt/beta-catenin pathways in women with postmenopausal osteoporosis: A pilot study. Bone 2018, 116, 42-46. [CrossRef]

70. Borsje, M.A.; Ren, Y.; de Haan-Visser, H.W.; Kuijer, R. Comparison of low-intensity pulsed ultrasound and pulsed electromagnetic field treatments on opg and rankl expression in human osteoblast-like cells. Angle Orthod. 2010, 80, 498-503. [CrossRef]

71. Schwartz, Z.; Fisher, M.; Lohmann, C.H.; Simon, B.J.; Boyan, B.D. Osteoprotegerin (opg) production by cells in the osteoblast lineage is regulated by pulsed electromagnetic fields in cultures grown on calcium phosphate substrates. Ann. Biomed. Eng. 2009, 37, 437-444. [CrossRef] [PubMed]

72. Chang, K.; Chang, W.H.; Huang, S.; Huang, S.; Shih, C. Pulsed electromagnetic fields stimulation affects osteoclast formation by modulation of osteoprotegerin, rank ligand and macrophage colony-stimulating factor. J. Orthop. Res. 2005, 23, 1308-1314. [CrossRef] [PubMed]

73. Wang, P.; Liu, J.; Yang, Y.; Zhai, M.; Shao, X.; Yan, Z.; Zhang, X.; Wu, Y.; Cao, L.; Sui, B.; et al. Differential intensity-dependent effects of pulsed electromagnetic fields on rankl-induced osteoclast formation, apoptosis, and bone resorbing ability in raw264.7 cells. Bioelectromagnetics 2017, 38, 602-612. [CrossRef] [PubMed]

74. Lei, T.; Li, F.; Liang, Z.; Tang, C.; Xie, K.; Wang, P.; Dong, X.; Shan, S.; Liu, J.; Xu, Q.; et al. Effects of four kinds of electromagnetic fields (emf) with different frequency spectrum bands on ovariectomized osteoporosis in mice. Sci. Rep. 2017, 7, 553. [CrossRef] [PubMed]

75. Ehnert, S.; van Griensven, M.; Unger, M.; Scheffler, H.; Falldorf, K.; Fentz, A.K.; Seeliger, C.; Schroter, S.; Nussler, A.K.; Balmayor, E.R. Co-culture with human osteoblasts and exposure to extremely low frequency pulsed electromagnetic fields improve osteogenic differentiation of human adipose-derived mesenchymal stem cells. Int. J. Mol. Sci. 2018, 19, 994. [CrossRef] [PubMed]

76. Bagheri, L.; Pellati, A.; Rizzo, P.; Aquila, G.; Massari, L.; De Mattei, M.; Ongaro, A. Notch pathway is active during osteogenic differentiation of human bone marrow mesenchymal stem cells induced by pulsed electromagnetic fields. J. Tissue Eng. Regen. Med. 2018, 12, 304-315. [CrossRef]

77. Goodman, R.; Lin-Ye, A.; Geddis, M.S.; Wickramaratne, P.J.; Hodge, S.E.; Pantazatos, S.P.; Blank, M.; Ambron, R.T. Extremely low frequency electromagnetic fields activate the erk cascade, increase hsp70 protein levels and promote regeneration in planaria. Int. J. Radiat. Biol. 2009, 85, 851-859. [CrossRef]

78. Lin, H.; Blank, M.; Rossol-Haseroth, K.; Goodman, R. Regulating genes with electromagnetic response elements. J. Cell. Biochem. 2001, 81, 143-148. [CrossRef]

79. Lu, T.; Huang, Y.X.; Zhang, C.; Chai, M.X.; Zhang, J. Effect of pulsed electromagnetic field therapy on the osteogenic and adipogenic differentiation of bone marrow mesenchymal stem cells. Genet. Mol. Res. GMR 2015, 14, 11535-11542. [CrossRef]

80. Martino, C.F.; Belchenko, D.; Ferguson, V.; Nielsen-Preiss, S.; Qi, H.J. The effects of pulsed electromagnetic fields on the cellular activity of saos-2 cells. Bioelectromagnetics 2008, 29, 125-132. [CrossRef]

81. Hannay, G.; Leavesley, D.; Pearcy, M. Timing of pulsed electromagnetic field stimulation does not affect the promotion of bone cell development. Bioelectromagnetics 2005, 26, 670-676. [CrossRef] [PubMed]

82. Cai, J.; Li, W.; Sun, T.; Li, X.; Luo, E.; Jing, D. Pulsed electromagnetic fields preserve bone architecture and mechanical properties and stimulate porous implant osseointegration by promoting bone anabolism in type 1 diabetic rabbits. Osteoporos. Int. 2018, 29, 1177-1191. [CrossRef] [PubMed]

83. Li, J.; Zeng, Z.; Zhao, Y.; Jing, D.; Tang, C.; Ding, Y.; Feng, X. Effects of low-intensity pulsed electromagnetic fields on bone microarchitecture, mechanical strength and bone turnover in type 2 diabetic $\mathrm{db} / \mathrm{db}$ mice. Sci. Rep. 2017, 7, 10834. [CrossRef] [PubMed]

84. Jing, D.; Cai, J.; Shen, G.; Huang, J.; Li, F.; Li, J.; Lu, L.; Luo, E.; Xu, Q. The preventive effects of pulsed electromagnetic fields on diabetic bone loss in streptozotocin-treated rats. Osteoporos. Int. 2011, 22, 1885-1895. [CrossRef] [PubMed] 
85. Lei, T.; Liang, Z.; Li, F.; Tang, C.; Xie, K.; Wang, P.; Dong, X.; Shan, S.; Jiang, M.; Xu, Q.; et al. Pulsed electromagnetic fields (pemf) attenuate changes in vertebral bone mass, architecture and strength in ovariectomized mice. Bone 2018, 108, 10-19. [CrossRef]

86. Li, B.; Bi, J.; Li, W.; Huang, S.; Zhang, S.; Zhao, J.; Meng, Q.; Fei, J. Effects of pulsed electromagnetic fields on histomorphometry and osteocalcin in disuse osteoporosis rats. Technol. Health Care 2017, 25, 13-20. [CrossRef]

87. Zhou, J.; Liao, Y.; Zeng, Y.; Xie, H.; Fu, C.; Li, N. Effect of intervention initiation timing of pulsed electromagnetic field on ovariectomy-induced osteoporosis in rats. Bioelectromagnetics 2017, 38, $456-465$. [CrossRef]

88. Zhou, J.; Liao, Y.; Xie, H.; Liao, Y.; Zeng, Y.; Li, N.; Sun, G.; Wu, Q.; Zhou, G. Effects of combined treatment with ibandronate and pulsed electromagnetic field on ovariectomy-induced osteoporosis in rats. Bioelectromagnetics 2017, 38, 31-40. [CrossRef]

89. Androjna, C.; Fort, B.; Zborowski, M.; Midura, R.J. Pulsed electromagnetic field treatment enhances healing callus biomechanical properties in an animal model of osteoporotic fracture. Bioelectromagnetics 2014, 35, 396-405. [CrossRef]

90. Park, P.; Lau, D.; Brodt, E.D.; Dettori, J.R. Electrical stimulation to enhance spinal fusion: A systematic review. Evid. Based Spine-Care J. 2014, 5, 87-94.

91. Hannemann, P.F.; Mommers, E.H.; Schots, J.P.; Brink, P.R.; Poeze, M. The effects of low-intensity pulsed ultrasound and pulsed electromagnetic fields bone growth stimulation in acute fractures: A systematic review and meta-analysis of randomized controlled trials. Arch. Orthop. Trauma Surg. 2014, 134, 1093-1106. [CrossRef] [PubMed]

92. Ryang We, S.; Koog, Y.H.; Jeong, K.I.; Wi, H. Effects of pulsed electromagnetic field on knee osteoarthritis: A systematic review. Rheumatology 2013, 52, 815-824. [CrossRef] [PubMed]

93. Vavken, P.; Arrich, F.; Schuhfried, O.; Dorotka, R. Effectiveness of pulsed electromagnetic field therapy in the management of osteoarthritis of the knee: A meta-analysis of randomized controlled trials. J. Rehabil. Med. 2009, 41, 406-411. [CrossRef] [PubMed]

94. Biering-Sorensen, F.; Hansen, B.; Lee, B.S. Non-pharmacological treatment and prevention of bone loss after spinal cord injury: A systematic review. Spinal Cord 2009, 47, 508-518. [CrossRef] [PubMed]

95. Walker, N.A.; Denegar, C.R.; Preische, J. Low-intensity pulsed ultrasound and pulsed electromagnetic field in the treatment of tibial fractures: A systematic review. J. Athl. Train. 2007, 42, 530-535.

96. Ebrahim, S.; Mollon, B.; Bance, S.; Busse, J.W.; Bhandari, M. Low-intensity pulsed ultrasonography versus electrical stimulation for fracture healing: A systematic review and network meta-analysis. Can. J. Surg. 2014, 57, E105-E118. [CrossRef]

97. Mollon, B.; da Silva, V.; Busse, J.W.; Einhorn, T.A.; Bhandari, M. Electrical stimulation for long-bone fracture-healing: A meta-analysis of randomized controlled trials. J. Bone Jt. Surg. Am. 2008, 90, 2322-2330. [CrossRef]

98. Aleem, I.S.; Aleem, I.; Evaniew, N.; Busse, J.W.; Yaszemski, M.; Agarwal, A.; Einhorn, T.; Bhandari, M. Efficacy of electrical stimulators for bone healing: A meta-analysis of randomized sham-controlled trials. Sci. Rep. 2016, 6, 31724. [CrossRef]

99. Barker, A.T.; Dixon, R.A.; Sharrard, W.J.; Sutcliffe, M.L. Pulsed magnetic field therapy for tibial non-union. Interim results of a double-blind trial. Lancet 1984, 1, 994-996. [CrossRef]

100. Shi, H.F.; Xiong, J.; Chen, Y.X.; Wang, J.F.; Qiu, X.S.; Wang, Y.H.; Qiu, Y. Early application of pulsed electromagnetic field in the treatment of postoperative delayed union of long-bone fractures: A prospective randomized controlled study. BMC Musculoskelet. Disord. 2013, 14, 35. [CrossRef]

101. Poll, G.; Monte, A.D.; Cosco, F. Treatment of congenital pseudarthrosis with endomedullary nail and low frequency pulsing electromagnetic fields: A controlled study. J. Bioelectr. 1985, 4, 195-210. [CrossRef]

102. Simonis, R.B.; Parnell, E.J.; Ray, P.S.; Peacock, J.L. Electrical treatment of tibial non-union: A prospective, randomised, double-blind trial. Injury 2003, 34, 357-362. [CrossRef]

103. Sharrard, W.J. A double-blind trial of pulsed electromagnetic fields for delayed union of tibial fractures. J. Bone Jt. Surg. Br. 1990, 72, 347-355. [CrossRef]

104. Murray, H.B.; Pethica, B.A. A follow-up study of the in-practice results of pulsed electromagnetic field therapy in the management of nonunion fractures. Orthop. Res. Rev. 2016, 8, 67-72. [CrossRef] [PubMed] 
105. Hernandez, R.K.; Do, T.P.; Critchlow, C.W.; Dent, R.E.; Jick, S.S. Patient-related risk factors for fracture-healing complications in the united kingdom general practice research database. Acta. Orthop. 2012, 83, 653-660. [CrossRef]

106. Massari, L.; Benazzo, F.; Falez, F.; Cadossi, R.; Perugia, D.; Pietrogrande, L.; Aloj, D.C.; Capone, A.; D'Arienzo, M.; Cadossi, M.; et al. Can clinical and surgical parameters be combined to predict how long it will take a tibia fracture to heal? A prospective multicentre observational study: The fracting study. BioMed Res. Int. 2018, 2018, 1809091. [CrossRef]

107. Neyeloff, J.L.; Fuchs, S.C.; Moreira, L.B. Meta-analyses and forest plots using a microsoft excel spreadsheet: Step-by-step guide focusing on descriptive data analysis. BMC Res. Notes 2012, 5, 52. [CrossRef]

108. Faldini, C.; Cadossi, M.; Luciani, D.; Betti, E.; Chiarello, E.; Giannini, S. Electromagnetic bone growth stimulation in patients with femoral neck fractures treated with screws: Prospective randomized double-blind study. Curr. Orthop. Pract. 2010, 21, 282-287. [CrossRef]

109. Martinez-Rondanelli, A.; Martinez, J.P.; Moncada, M.E.; Manzi, E.; Pinedo, C.R.; Cadavid, H. Electromagnetic stimulation as coadjuvant in the healing of diaphyseal femoral fractures: A randomized controlled trial. Colomb. Med. 2014, 45, 67-71.

110. Adie, S.; Harris, I.A.; Naylor, J.M.; Rae, H.; Dao, A.; Yong, S.; Ying, V. Pulsed electromagnetic field stimulation for acute tibial shaft fractures: A multicenter, double-blind, randomized trial. J. Bone Jt. Surg. Am. 2011, 93, 1569-1576. [CrossRef]

111. Hannemann, P.F.; Gottgens, K.W.; van Wely, B.J.; Kolkman, K.A.; Werre, A.J.; Poeze, M.; Brink, P.R. The clinical and radiological outcome of pulsed electromagnetic field treatment for acute scaphoid fractures: A randomised double-blind placebo-controlled multicentre trial. J. Bone Jt. Surg. Br. 2012, 94, 1403-1408. [CrossRef] [PubMed]

112. Hannemann, P.F.; van Wezenbeek, M.R.; Kolkman, K.A.; Twiss, E.L.; Berghmans, C.H.; Dirven, P.A.; Brink, P.R.; Poeze, M. Ct scan-evaluated outcome of pulsed electromagnetic fields in the treatment of acute scaphoid fractures: A randomised, multicentre, double-blind, placebo-controlled trial. Bone Jt. J. 2014, 96, 1070-1076. [CrossRef] [PubMed]

113. Cheing, G.L.; Wan, J.W.; Kai Lo, S. Ice and pulsed electromagnetic field to reduce pain and swelling after distal radius fractures. J. Rehabil. Med. 2005, 37, 372-377. [CrossRef] [PubMed]

114. Lazovic, M.; Kocic, M.; Dimitrijevic, L.; Stankovic, I.; Spalevic, M.; Ciric, T. Pulsed electromagnetic field during cast immobilization in postmenopausal women with colles' fracture. Srp. Arh. Za Celok. Lek. 2012, 140, 619-624. [CrossRef]

115. Jin, J.; Sklar, G.E.; Min Sen Oh, V.; Chuen Li, S. Factors affecting therapeutic compliance: A review from the patient's perspective. Clin. Risk Manag. 2008, 4, 269-286.

116. Borsalino, G.; Bagnacani, M.; Bettati, E.; Fornaciari, F.; Rocchi, R.; Uluhogian, S.; Ceccherelli, G.; Cadossi, R.; Traina, G.C. Electrical stimulation of human femoral intertrochanteric osteotomies. Double-blind study. Clin. Orthop. Relat. Res. 1988, 237, 256-263.

117. Mammi, G.I.; Rocchi, R.; Cadossi, R.; Massari, L.; Traina, G.C. The electrical stimulation of tibial osteotomies. Double-blind study. Clin. Orthop. Relat. Res. 1993, 288, 246-253. [CrossRef]

118. Eyres, K.S.; Saleh, M.; Kanis, J.A. Effect of pulsed electromagnetic fields on bone formation and bone loss during limb lengthening. Bone 1996, 18, 505-509. [CrossRef]

119. Luna Gonzalez, F.; Lopez Arevalo, R.; Meschian Coretti, S.; Urbano Labajos, V.; Delgado Rufino, B. Pulsed electromagnetic stimulation of regenerate bone in lengthening procedures. Acta Orthop. Belg. 2005, 71, 571-576.

120. Ziegler, P.N.; Nussler, A.K.; Wilbrand, B.; Falldorf, K.; Springer, F.; Fentz, A.K.; Eschenburg, G.; Ziegler, A.; Stöckle, U.; Wintermeyer, E.; et al. Pulsed electromagnetic field therapy improves osseous consolidation after high tibial osteotomy in elderly patients-A randomized, placebo-controlled, double-blind trial. J. Clin. Med. 2019, 8, 2008. [CrossRef]

121. Abdelrahim, A.; Hassanein, H.R.; Dahaba, M. Effect of pulsed electromagnetic field on healing of mandibular fracture: A preliminary clinical study. J. Oral Maxillofac. Surg. 2011, 69, 1708-1717. [CrossRef] [PubMed]

122. Dallari, D.; Fini, M.; Giavaresi, G.; Del Piccolo, N.; Stagni, C.; Amendola, L.; Rani, N.; Gnudi, S.; Giardino, R. Effects of pulsed electromagnetic stimulation on patients undergoing hip revision prostheses: A randomized prospective double-blind study. Bioelectromagnetics 2009, 30, 423-430. [CrossRef] [PubMed] 
123. Li, S.; Jiang, H.; Wang, B.; Gu, M.; Bi, X.; Yin, Y.; Wang, Y. Magnetic resonance spectroscopy for evaluating the effect of pulsed electromagnetic fields on marrow adiposity in postmenopausal women with osteopenia. J. Comput. Assist. Tomogr. 2018, 42, 792-797. [CrossRef] [PubMed]

124. Elsisi, H.F.; Mousa, G.S.; ELdesoky, M.T. Electromagnetic field versus circuit weight training on bone mineral density in elderly women. Clin. Interv. Aging 2015, 10, 539-547. [PubMed]

125. Tabrah, F.; Hoffmeier, M.; Gilbert, F., Jr.; Batkin, S.; Bassett, C.A. Bone density changes in osteoporosis-prone women exposed to pulsed electromagnetic fields (pemfs). J. Bone Min. Res. 1990, 5, 437-442. [CrossRef]

126. Liu, H.F.; Yang, L.; He, H.C.; Zhou, J.; Liu, Y.; Wang, C.Y.; Wu, Y.C.; He, C.Q. Pulsed electromagnetic fields on postmenopausal osteoporosis in southwest china: A randomized, active-controlled clinical trial. Bioelectromagnetics 2013, 34, 323-332. [CrossRef] [PubMed]

127. Mooney, V. A randomized double-blind prospective study of the efficacy of pulsed electromagnetic fields for interbody lumbar fusions. Spine 1990, 15, 708-712. [CrossRef]

128. Jenis, L.G.; An, H.S.; Stein, R.; Young, B. Prospective comparison of the effect of direct current electrical stimulation and pulsed electromagnetic fields on instrumented posterolateral lumbar arthrodesis. J. Spinal Disord. 2000, 13, 290-296. [CrossRef]

129. Risso Neto, M.I.; Zuiani, G.R.; Cavali, P.D.M.; Veiga, I.G.; Pasqualini, W.; Amato Filho, A.C.S.; Cliquet Júnior, A.; Landim, E.; Miranda, J.B.D. Effect of pulsed electromagnetic fields on the consolidation of posterolateral arthrodeses in the lumbosacral spine: A prospective, double-blind, randomized study. Coluna/Columna 2017, 16, 206-212. [CrossRef]

130. Foley, K.T.; Mroz, T.E.; Arnold, P.M.; Chandler, H.C., Jr.; Dixon, R.A.; Girasole, G.J.; Renkens, K.L., Jr.; Riew, K.D.; Sasso, R.C.; Smith, R.C.; et al. Randomized, prospective, and controlled clinical trial of pulsed electromagnetic field stimulation for cervical fusion. Spine J. 2008, 8, 436-442. [CrossRef]

131. Haefeli, M.; Elfering, A. Pain assessment. Eur. Spine J. 2006, 15 (Suppl. 1), S17-S24. [CrossRef] [PubMed]

132. Fairbank, J.C.; Couper, J.; Davies, J.B.; O’Brien, J.P. The oswestry low back pain disability questionnaire. Physiotherapy 1980, 66, 271-273. [PubMed]

133. Omar, A.S.; Awadalla, M.A.; El-Latif, M.A. Evaluation of pulsed electromagnetic field therapy in the management of patients with discogenic lumbar radiculopathy. Int. J. Rheum. Dis. 2012, 15, e101-e108. [CrossRef] [PubMed]

134. Bolognese, J.A.; Schnitzer, T.J.; Ehrich, E.W. Response relationship of vas and likert scales in osteoarthritis efficacy measurement. Osteoarthr. Cartil. 2003, 11, 499-507. [CrossRef]

135. Walker, L.C.; Clement, N.D.; Bardgett, M.; Weir, D.; Holland, J.; Gerrand, C.; Deehan, D.J. The womac score can be reliably used to classify patient satisfaction after total knee arthroplasty. Knee Surg. Sports Traumatol. Arthrosc. 2018, 26, 3333-3341. [CrossRef]

136. Roos, E.M.; Lohmander, L.S. The knee injury and osteoarthritis outcome score (koos): From joint injury to osteoarthritis. Health Qual. Life Outcomes 2003, 1, 64. [CrossRef]

137. Soucie, J.M.; Wang, C.; Forsyth, A.; Funk, S.; Denny, M.; Roach, K.E.; Boone, D.; Hemophilia Treatment Center, N. Range of motion measurements: Reference values and a database for comparison studies. Haemophilia 2011, 17, 500-507. [CrossRef]

138. Trock, D.H.; Bollet, A.J.; Markoll, R. The effect of pulsed electromagnetic fields in the treatment of osteoarthritis of the knee and cervical spine. Report of randomized, double blind, placebo controlled trials. J. Rheumatol. 1994, 21, 1903-1911.

139. Prevoo, M.L.; van Riel, P.L.; van't Hof, M.A.; van Rijswijk, M.H.; van Leeuwen, M.A.; Kuper, H.H.; van de Putte, L.B. Validity and reliability of joint indices. A longitudinal study in patients with recent onset rheumatoid arthritis. Br. J. Rheumatol. 1993, 32, 589-594. [CrossRef]

140. Devlin, N.J.; Brooks, R. Eq-5d and the euroqol group: Past, present and future. Appl. Health Econ. Health Policy 2017, 15, 127-137. [CrossRef]

141. Turner-Stokes, L.; Tonge, P.; Nyein, K.; Hunter, M.; Nielson, S.; Robinson, I. The northwick park dependency score (npds): A measure of nursing dependency in rehabilitation. Clin. Rehabil. 1998, 12, 304-318. [CrossRef] [PubMed]

142. Sutbeyaz, S.T.; Sezer, N.; Koseoglu, B.F. The effect of pulsed electromagnetic fields in the treatment of cervical osteoarthritis: A randomized, double-blind, sham-controlled trial. Rheumatol. Int. 2006, 26, 320-324. [CrossRef] [PubMed] 
143. Reilingh, M.L.; van Bergen, C.J.; Gerards, R.M.; van Eekeren, I.C.; de Haan, R.J.; Sierevelt, I.N.; Kerkhoffs, G.M.; Krips, R.; Meuffels, D.E.; van Dijk, C.N.; et al. Effects of pulsed electromagnetic fields on return to sports after arthroscopic debridement and microfracture of osteochondral talar defects: A randomized, double-blind, placebo-controlled, multicenter trial. Am. J. Sports Med. 2016, 44, 1292-1300. [CrossRef] [PubMed]

144. Cadossi, M.; Buda, R.E.; Ramponi, L.; Sambri, A.; Natali, S.; Giannini, S. Bone marrow-derived cells and biophysical stimulation for talar osteochondral lesions: A randomized controlled study. Foot Ankle Int. 2014, 35, 981-987. [CrossRef]

145. Trock, D.H.; Bollet, A.J.; Dyer, R.H., Jr.; Fielding, L.P.; Miner, W.K.; Markoll, R. A double-blind trial of the clinical effects of pulsed electromagnetic fields in osteoarthritis. J. Rheumatol. 1993, 20, 456-460. [CrossRef]

146. Pipitone, N.; Scott, D.L. Magnetic pulse treatment for knee osteoarthritis: A randomised, double-blind, placebo-controlled study. Curr. Med. Res. Opin. 2001, 17, 190-196. [CrossRef]

147. Thamsborg, G.; Florescu, A.; Oturai, P.; Fallentin, E.; Tritsaris, K.; Dissing, S. Treatment of knee osteoarthritis with pulsed electromagnetic fields: A randomized, double-blind, placebo-controlled study. Osteoarthr. Cartil. 2005, 13, 575-581. [CrossRef]

148. Fischer, G.; Pelka, R.B.; Barovic, J. Adjuvant treatment of knee osteoarthritis with weak pulsing magnetic fields. Results of a placebo-controlled trial prospective clinical trial. Z. Orthop. Ihre Grenzgeb. 2005, 143, 544-550. [CrossRef]

149. Lee, P.; Kim, Y.; Lim, Y.; Lee, C.; Choi, S.; Park, S.; Lee, J.; Lee, S. Efficacy of pulsed electromagnetic therapy for chronic lower back pain: A randomized, double-blind, placebo-controlled study. J. Int. Med. Res. 2006, 34, 160-167. [CrossRef]

150. Ay, S.; Evcik, D. The effects of pulsed electromagnetic fields in the treatment of knee osteoarthritis: A randomized, placebo-controlled trial. Rheumatol. Int. 2009, 29, 663-666. [CrossRef]

151. Ozguclu, E.; Cetin, A.; Cetin, M.; Calp, E. Additional effect of pulsed electromagnetic field therapy on knee osteoarthritis treatment: A randomized, placebo-controlled study. Clin. Rheumatol. 2010, 29, 927-931. [CrossRef] [PubMed]

152. Iannitti, T.; Fistetto, G.; Esposito, A.; Rottigni, V.; Palmieri, B. Pulsed electromagnetic field therapy for management of osteoarthritis-related pain, stiffness and physical function: Clinical experience in the elderly. Clin. Interv. Aging 2013, 8, 1289-1293. [CrossRef] [PubMed]

153. Dundar, U.; Asik, G.; Ulasli, A.M.; Sinici, S.; Yaman, F.; Solak, O.; Toktas, H.; Eroglu, S. Assessment of pulsed electromagnetic field therapy with serum ykl-40 and ultrasonography in patients with knee osteoarthritis. Int. J. Rheum. Dis. 2016, 19, 287-293. [CrossRef] [PubMed]

154. Daish, C.; Blanchard, R.; Fox, K.; Pivonka, P.; Pirogova, E. The application of pulsed electromagnetic fields (pemfs) for bone fracture repair: Past and perspective findings. Ann. Biomed. Eng. 2018, 46, 525-542. [CrossRef] 